\title{
Multiphase Calcite Cementation and Fluids Evolution of a Deeply Buried Carbonate Reservoir in the Upper Ordovician Lianglitag Formation, Tahe Oilfield, Tarim Basin, NW China
}

\author{
Jiaqing Liu, ${ }^{1}$ Zhong Li, ${ }^{1}$ Lijuan Cheng, ${ }^{1}$ and Jiawei $\mathrm{Li}^{2}$ \\ ${ }^{1}$ Institute of Geology and Geophysics, Chinese Academy of Sciences, Beijing 100029, China \\ ${ }^{2}$ Research Institute of Tsinghua, Pearl River Delta, Guangzhou 510530, China \\ Correspondence should be addressed to Zhong Li; lizhong@mail.igcas.ac.cn
}

Received 2 March 2017; Revised 9 May 2017; Accepted 28 May 2017; Published 1 August 2017

Academic Editor: Zhijun Jin

Copyright (C) 2017 Jiaqing Liu et al. This is an open access article distributed under the Creative Commons Attribution License, which permits unrestricted use, distribution, and reproduction in any medium, provided the original work is properly cited.

\begin{abstract}
Oil and gas have been found in the Upper Ordovician Lianglitag Formation carbonates in the Tahe Oilfield, Tarim Basin, NW China. This study documents the origin of diagenetic fluids by using a combination of petrology, SIMS, fluid inclusion, and radiogenic isotope analysis. Six stages of calcite cements were revealed. C1-C2 formed in marine to early burial environments. $\mathrm{C} 3$ has relatively low $\delta^{18} \mathrm{O}_{\mathrm{VPDB}}$ values $(-8.45 \%$ o to $-6.50 \%$ ) and likely has a meteoric origin. Meteoric water probably fluxed into aquifers during the Early Paleozoic and Late Paleozoic uplift. C4 has $\delta^{18} \mathrm{O}_{\mathrm{VPDB}}$ values typically $3 \%$ higher than those of C3, and probably formed during shallow burial. C5 displays relatively negative $\delta^{18} \mathrm{O}_{\mathrm{VPDB}}$ values $(-8.26 \%$ o to $-5.12 \%$ ), and the moderate-tohigh fluid-inclusion temperatures imply that it precipitated in burial environments. C6 shows homogenization temperatures (up to $200^{\circ} \mathrm{C}$ ) higher than the maximum burial and much lower salinities $(<10.61 \mathrm{wt} \% \mathrm{NaCl})$, which may suggest that the fluid was deeply recycled meteoric water. The average ${ }^{87} \mathrm{Sr} /{ }^{86} \mathrm{Sr}$ ratios of fracture- and vug-filling calcite cements are much higher, indicative of incorporation of radiogenic Sr. Caves and fractures constitute the dominant reservoir spaces. A corresponding diagenesis-related reservoir evolution model was established that favors exploration and prediction.
\end{abstract}

\section{Introduction}

Fluid origin and flow in sedimentary basins have an important influence on various diagenetic alteration processes, including cementation, dissolution, recrystallization, and dolomitization, which have significant impacts on reservoir development [1-10]. Thus, constraining the origin and evolution of fluid and fluid flow events is of considerable significance for hydrocarbon exploration and reservoir development. Fluid is not only a component of the fluid-rock interaction but also a carrier of matter and energy in the fluid-rock interaction. Fluid is an active control factor of the fluid-rock interaction system [7, 10, 11]. However, for deeply buried reservoirs, due to their complicated burial and tectonic history, the fluid chemical composition and flow are very complicated; therefore, understanding and predicting fluid flow are still challenging.

The Tahe Oilfield, located within the Tabei tectonic block in the northern part of the basin, is the largest Paleozoic marine oilfield in China. For the Tahe Oilfield, the current main oil-gas production layer is the Middle Ordovician Yijianfang Formation and the Early Middle Ordovician Yingshan Formation, and considerable previous works have been done on these layers [12-17]. By contrast, carbonate rocks of the Upper Ordovician Lianglitag Formation are potential exploration strata, which have received little attention. The carbonates of the Upper Ordovician Lianglitag Formation are deeply buried, with depths $>4500 \mathrm{~m}$. Previous studies mainly focused on the biostratigraphy, lithostratigraphy [18-20], and sedimentary environment [21-23]. Lu et al. [24] analyzed the main reservoir characteristics of the Lianglitag Formation: the matrix of the Lianglitag Formation is characterized by low porosity and permeability, with strong reservoir heterogeneity.

In situ Secondary Ion Mass Spectrometry (SIMS) has provided a powerful technique for studying basin fluid activities [25-30]. SIMS can solve the traditional test difficulties; for example, a small number of samples cannot meet the test 
requirements or the analysis results are often the average value of multiphase fluid mixing. In this paper, for the first time, in situ SIMS analysis has been used to characterize different fluids and discriminate their nature in study areas.

This paper takes the carbonate reservoirs of the Upper Ordovician Lianglitag Formation as a typical example and focuses on the activities of diagenetic fluids as well as their effects on reservoir development under a complex multistage tectonic setting. This work can provide useful insights into fluid evolution during diagenesis for typical deeply buried reservoirs. Specifically, we address the following questions:

(1) What are the petrological and geochemical characteristics of diagenetic calcites in the Late Ordovician Lianglitag Formation?

(2) What is the nature of the fluids and their impact on the Lianglitag Formation?

(3) What mechanisms were responsible for the formation of the carbonate reservoir of the Lianglitag Formation in the Tahe Oilfield in the Tarim Basin?

(4) What is the model for diagenetic fluid flow and reservoir performance in deeply buried carbonate successions?

\section{Geological Background}

The Tarim Basin, located in southern Xinjiang province, northwestern China, is surrounded by the Tian Shan, Kunlun, and Altyn mountains to the north, southwest, and southeast, respectively (Figure 1(a)). It is a multicycle composite basin with continental crust, composed of preSinian basaltic basins, which are formed by prototypical basins with different properties in different periods [32, 33]. The basin can be divided into seven tectonic units: Kuqa Depression, Tabei Uplift, North Depression (ManjiaerAwati Depressions), Central Uplift, Southwest Depression, Southeast Uplift, and Southeast Depression [32] (Figure 1(a)). The Tahe Oilfield, covering an area of $2400 \mathrm{~km}^{2}$, is located in the Akekule uplift in the eastern part of the Tabei Uplift (Figures 1(a) and 1(b)).

The warm and humid Ordovician climate provided favorable conditions for carbonate deposition on the Tarim Plate, which was situated at $20^{\circ} \mathrm{S}$ (Fang et al. 2001). From bottom to top, the Lower-Middle Ordovician strata are divided into the Penglaiba Formation $\left(\mathrm{O}_{1} p\right)$, Yingshan Fm. $\left(\mathrm{O}_{1-2} y\right)$, and Yijianfang Formation $\left(\mathrm{O}_{2} y j\right)$, whereas the Upper Ordovician strata are divided into the Qiaerbak Formation $\left(\mathrm{O}_{3} q\right)$, Lianglitag Formation $\left(\mathrm{O}_{3} l\right)$, and Sangtamu Formation $\left(\mathrm{O}_{3} s\right)$ (Figure 2). The Early Ordovician paleogeographic framework of the study area was characterized by the widespread development of carbonate platforms that were open to the sea in an extensional setting [14]. The buildup of carbonate platforms of the Lianglitag Formation was much lower than that of typical Early to Middle Ordovician platforms as a result of the sea-level rise [34], with a maximum thickness of $145.5 \mathrm{~m}$.

Core and detailed well log, seismic, and other exploration well data analyses indicate that, during the early stage, the Tahe region was characterized by a gentle slope with few high-energy depositions and characterized by grey to dark grey, thick-bedded micrites and microcrystalline marls interbedded with brown to grey-brown, thin- to mediumbedded bioclastic micrites and granular, microcrystalline limestones, whereas, at the late stage, it evolved into a weakrimmed platform, characterized by the deposition of highenergy platform margin facies. The platform margin facies are distributed in TP5, S116, S110, and S107 wells, which are characterized by sparite oolitic limestone, calcarenite, and bioclastic limestone. Towards the south, the platform was mainly composed of dark grey, thinly laminated, nodular micrite, indicative of slope deposition (Figure 1(b)) $[22,23]$.

Previous studies $[23,35]$ have shown that there is an unconformity between the top of the Lianglitag Formation and the overlying Sangtamu Formation (EPU) (Figure 2), indicating a regional exposure surface and depositional break. The southward subduction of the Tianshan Ocean and formation of its associated suture at the end of Middle Devonian time resulted in thrusting and uplifting in the north of the Tahe Oilfield was significantly greater than in the south [31,36] and led to the Upper Ordovician Lianglitag strata in the north being completely or partly removed by erosion, showing as the Lianglitag Fm. strata were overlain by the Carboniferous, the Devonian, or Silurian strata (LPU) (Figures 1(c) and 2), whereas the Lianglitag strata remained in the south (Figures 1(b) and 1(c)). In this paper, based on previous works on the basic geology of the Tarim Basin [31, 37-39], the burial history of well S109 was rebuilt by the Basinmod 1D software and the Easy\% Ro model. During the deposition of the Ordovician, the uplift of the Tahe area led to the denudation of the strata. After the Ordovician deposited, the burial history was roughly divided into two stages by the two periods of uplift at the SilurianCarboniferous and Permian. There are many periods of weak erosion events, and, during the Neogene and Quaternary, the strata experienced rapid subsidence, leading to thick deposition. The Upper Ordovician strata have been buried to $>4500 \mathrm{~m}$, with paleotemperatures up to approximately $130^{\circ} \mathrm{C}$ (Figure 3).

\section{Methods}

This study is based on a detailed examination of 32 wells from the Tahe Oilfield. The description of cores focused on diagenetic features and also noted the lithology, depositional composition, and textures, as well as sedimentary structures. The petrographic examination of 120 thin sections of the diagenetic features and associated fabrics was completed using transmitted light and cathodoluminescence microscopy (CL, using a RELIOTRON, model RELION III; $5-8 \mathrm{kV}$ and 300-400 $\mu \mathrm{A}$ gun current) at the Diagenesis Laboratory of Institute of Geology and Geophysics, Chinese Academy of Sciences (IGGCAS).

To study the fluid nature of vug-filling calcite cement, in situ $\delta^{13} \mathrm{C}$ and $\delta^{18} \mathrm{O}$ measurements were conducted using an in situ SIMS (Secondary Ion Mass Spectrometry) Cameca IMS-1280 ion microprobe at IGGCAS. The analytical procedures were similar to those described by Rollion-Bard et al. (2003). A $10-15 \mu \mathrm{m}$ diameter Cs ion beam was used to 


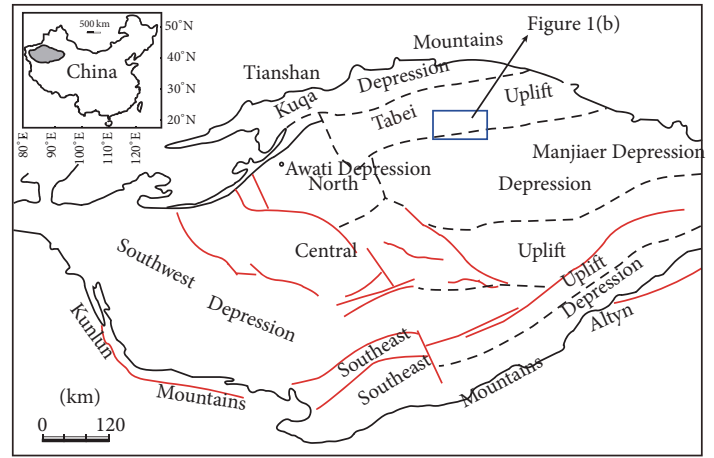

(a)

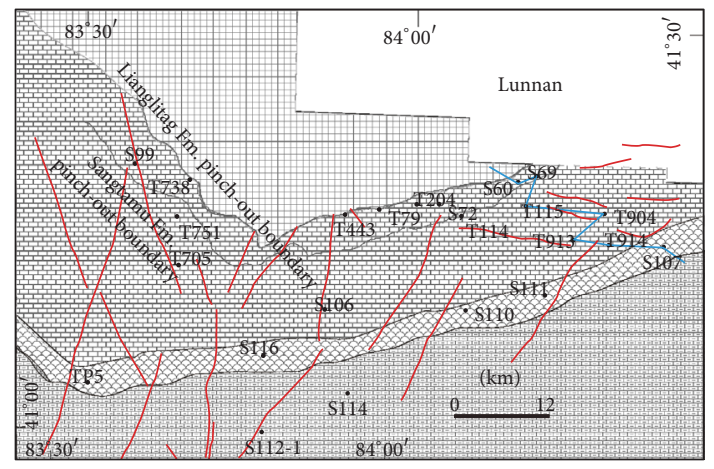

(b)

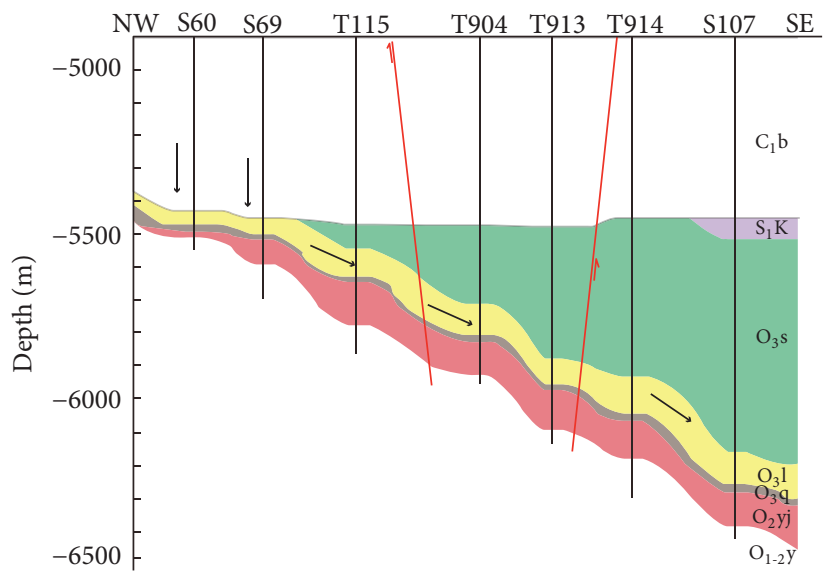

(c)

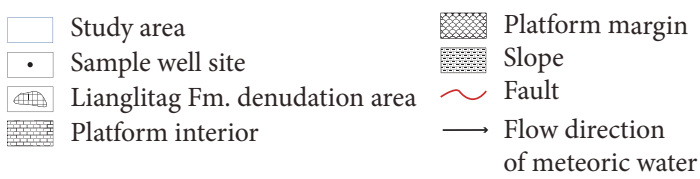

FIGURE 1: Tectonic subdivisions and location of the study areas. (a) Tectonic unit divisions of the Tarim Basin and location of the study areas. (b) Distribution of sample wells in the Tahe study region. (c) Strata profile from Well S60 to Well S107 (please see the blue line in (b)).

ablate $10-15 \mu \mathrm{m}$ diameter spots from the sample. The internal precision for each spot ranged between 0.009 and 0.015 (\% Standard Error). The external precision was estimated to be $0.4 \%$ o for oxygen and $0.6 \%$ for carbon as determined by consecutive analysis of a UWC (international calcite standard from University of Wisconsin) standard and OKA (Chinese primary calcite standard number GBW04481) standard.
44 core samples from 15 wells were collected for conventional oxygen and carbon isotope analyses. The samples analyzed in this study were whole rocks and fracture- and vug-filling calcite cement. Samples were taken using a dental drill. The analyses were carried out at the C-O Isotope Laboratory at IGGCAS. The carbon and oxygen isotope compositions were determined using a MAT-251 mass spectrometer 


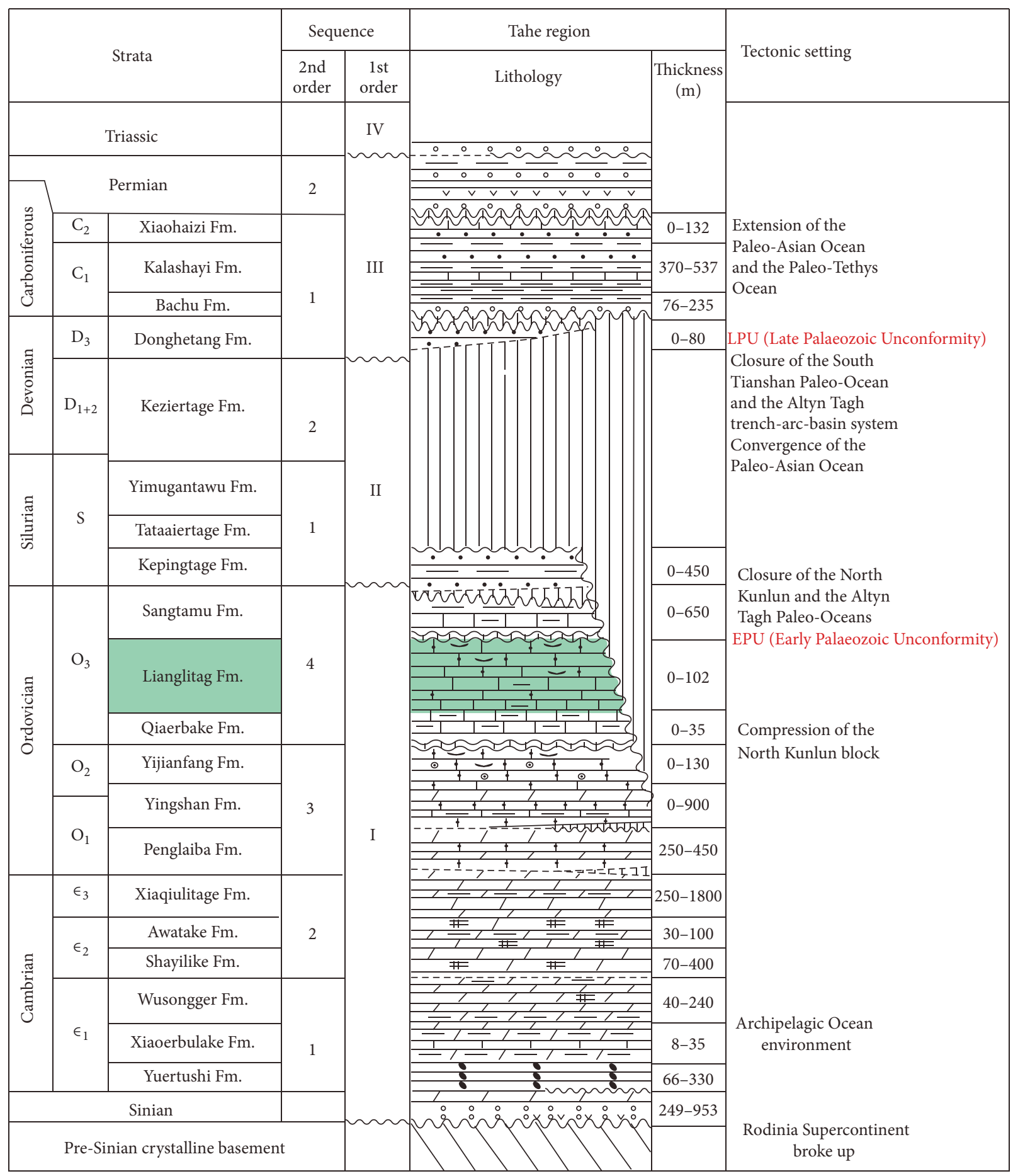

Volcanic rock

Intraclastic grainstone

涪 Phosphorite

Dolomite
琵䇥 Rocksalt

Argillaceous dolostone

Conglomerate

IIII) Stratum-absence
Clay

WW Regional unconformity

:-: Sandstone

$m$ Local unconformity
Argillaceous limestone

-- Disconformity

Bioclastic limestone

$\square$ Study strata

FIgURE 2: Stratigraphic chart showing the formations and hiatuses, modified after Lin et al. [31]. 


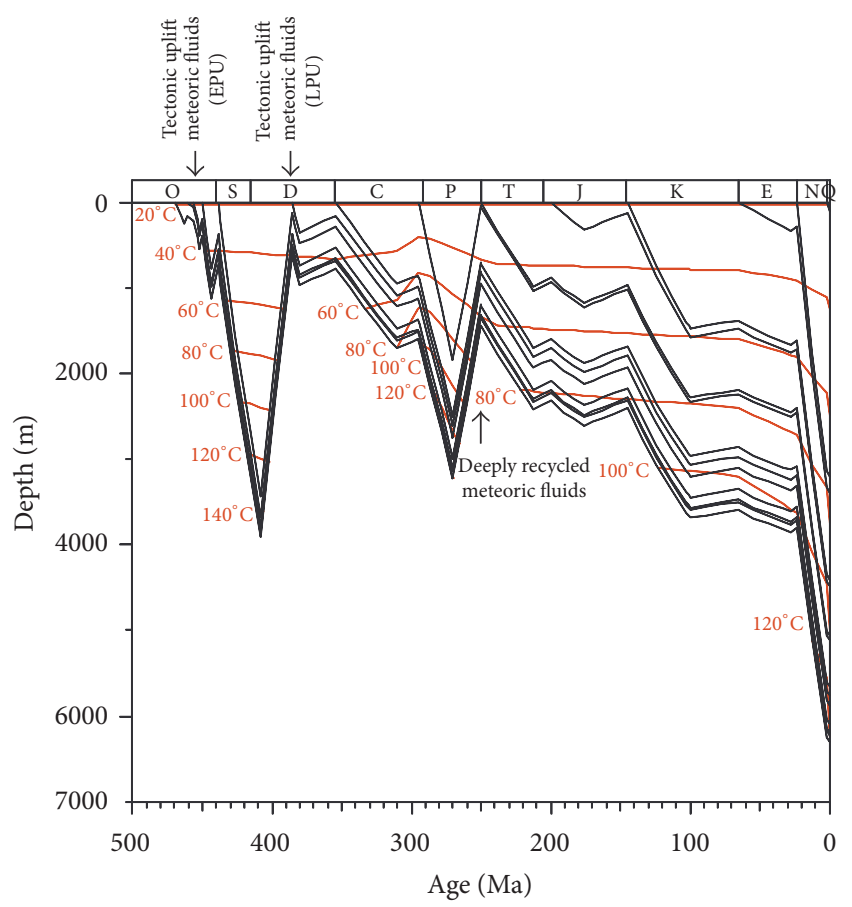

FIGURE 3: Burial history diagram of Well S109 in the Tahe Oilfield.

(Vienna PeeDee belemnite [VPDB] standard), and the results were expressed in parts per thousand (delta units). Reproducibility was checked by replicate analysis of laboratory standards and was $\pm 0.05 \%$ o $(1 \sigma)$ for oxygen isotopes and $\pm 0.02 \%$ o $(1 \sigma)$ for carbon isotopes.

26 core samples from 7 wells were collected for ${ }^{87} \mathrm{Sr} /{ }^{86} \mathrm{Sr}$ analyses. Strontium isotope analyses were performed at the $\mathrm{Rb}$-Sr Isotope Ultraclean Laboratory at IGGCAS. HAc was used to dissolve calcite to release Sr. The isotopic ratios were measured on a VG354 solid source mass spectrometer. The measured ${ }^{87} \mathrm{Sr} /{ }^{86} \mathrm{Sr}$ values were corrected using a quality fractionation standard of ${ }^{86} \mathrm{Sr} /{ }^{88} \mathrm{Sr}=0.1194$; the mean value of the measured strontium isotope NBS987 (standard sample) was $0.710272 \pm 0.000012$.

Fluid inclusion petrography and microthermometry were conducted on 25 samples of intergranular calcite cement and vug-fill calcite cement to measure the homogenization temperature ( $T_{h}$, uncorrected for pressure) and salinity of the aqueous fluid inclusions. The salinity, in weight percent of $\mathrm{NaCl}$ equivalents, was calculated from the ice melting temperature $\left(T_{m}\right.$ ice) using the Bodnar [40] equation with a temperature step increase of $2^{\circ} \mathrm{C} / \mathrm{min}$. Special emphasis was placed on fluid inclusion assemblages (FIAs) [41], which represent the most finely discriminated petrographically associated groups of fluid inclusions, which were presumably trapped at approximately the same time. The measurements were performed using a Linkam THMGS600 heatingfreezing stage with a $0.1^{\circ} \mathrm{C}$ precision and calibrated with synthetic pure water and $\mathrm{CO}_{2}$ inclusions. The analyses were conducted at the Diagenesis Laboratory at IGGCAS.

\section{Results}

\subsection{Petrographic Description}

\subsubsection{Cement Sequences}

Calcite Cement 1 (C1). C1 consists of isopachous fringe or fibrous (IFC) and early inclusion-poor calcite cement, constituting the first diagenetic phase to occlude the depositional pore space. IFC cement is noted for its blotchy to nonluminescent appearance under cathodoluminescence (CL) microscopy and is consistently present in grainstones and packstones (Figures 4(a) and 4(b)).

Calcite Cement 2 (C2). C2 is characterized by drusy calcite cement postdating calcite $\mathrm{Cl}$ and displays growth zones of dark red luminescence under CL (Figures 4(a) and 4(b)).

Calcite Cement 3 (C3). C3 is a blocky calcite and is characterized by nonluminescence (Figures 4(c)-4(f)). C3 occurs not only in intraparticle and interparticle pores but also in vug. The volume of $\mathrm{C} 3$ varies with its stratigraphic position. It has been widely observed in cores within the Lianglitag Formation pinch-out boundary and Sangtamu Formation pinch-out boundary, shown in Figures 5(a) and 5(b). At the south of the Sangtamu Formation pinch-out, C3 mainly occurs in the wells that are close to the fracture.

Calcite Cement 4 (C4). C4 grows on top of C3 crystals and exhibits a bright orange luminescent zoned CL pattern. It has euhedral surfaces that show no signs of dissolution. The percentage of $\mathrm{C} 3$ and $\mathrm{C} 4$ can reach $80 \%$ in some wells (Figures $4(\mathrm{c})$ and $4(\mathrm{~d}))$.

Calcite Cement 5 (C5). C5 is a clear calcite with brown to dull luminescence (Figures 4(e) and 4(f)). It occurs as isolated rhombic crystals or completely fills the pore space with blocky textures. Some dissolution likely occurred in $\mathrm{C} 5$ filled with oil and/or bitumen (Figures 4(e) and 4(f)).

Calcite Cement 6 (C6). The mineralogical characteristics of C6 are similar to those of C5, which has bright and thick crystals. Under luminescence, C6 mainly shows red luminescence (Figures 5(c) and 5(d)). C6 is closely associated with fractures that only present in wells where fractures were developed (Figures 5(e) and 5(f)).

4.1.2. Dissolution and Fracturing. Millimeter- to meter-scale dissolution features and fractures were observed in cores and suggestive of multiple dissolution events.

Early meteoric dissolution occurred locally in highenergy carbonate shoals, but this dissolution pore space was subsequently filled by late calcite cement (Figure 6(a)), with few effective fabric-selected pores reserved. Dissolution vugs and channels, with sizes up to several centimeters, were observed locally, and these vugs were mainly filled by calcite C3. The dissolution vugs were non-fabric-selective (Figure 6(b)) and were distributed along fractures (Figure 6(c)). Meter scale dissolution cavities were detected in some cores, with two types of cavity fillings. One was characterized by 


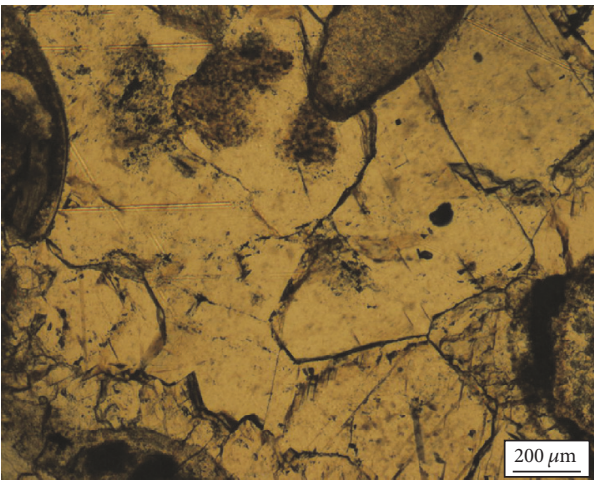

(a)

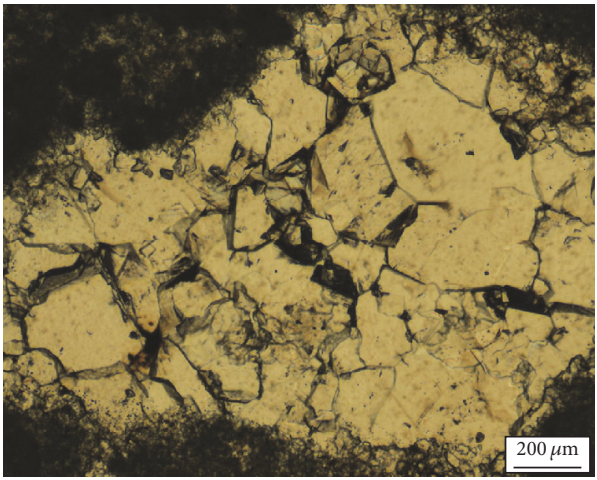

(c)

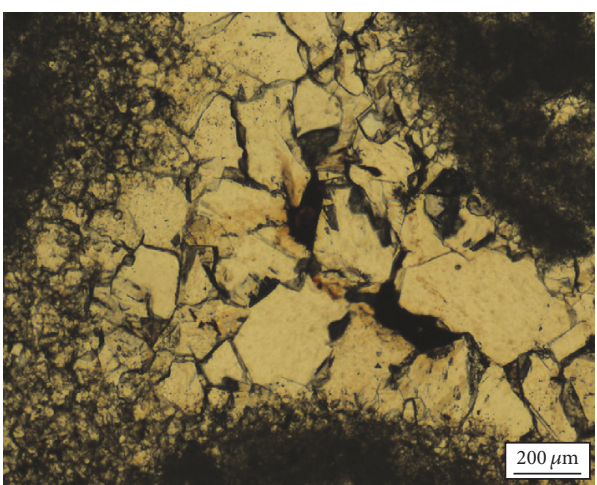

(e)

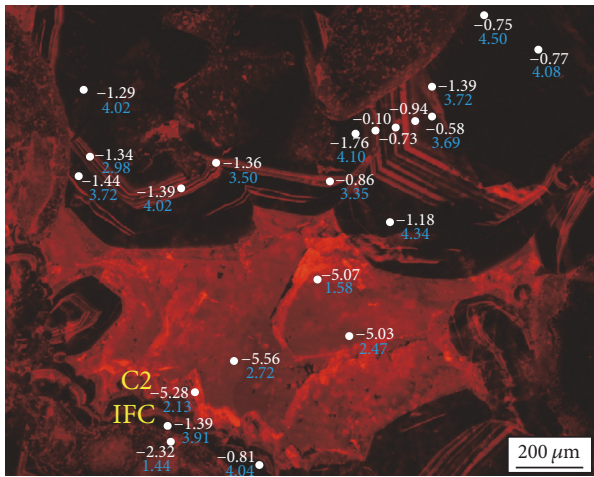

(b)

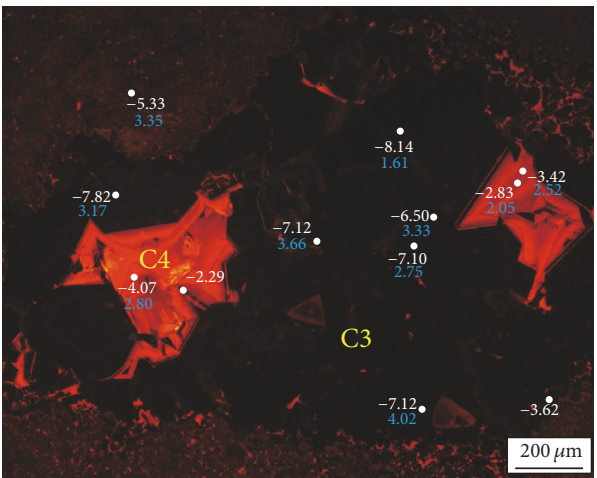

(d)

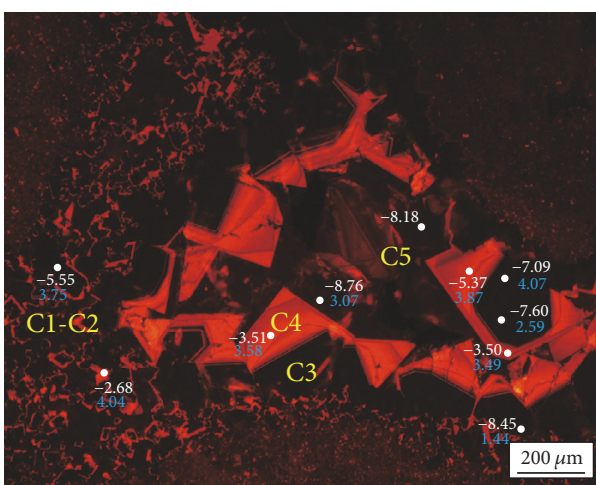

(f)

FIGURE 4: Photomicrograph pairs in transmitted light (a, c, and e) and cathodoluminescence (b, d, and f) of samples illustrating the main cement features in Lianglitag Fm. carbonate rocks. The white circle is the position of the SIM analysis point; the white digit is $\delta^{18} \mathrm{O}$ and the blue digit is $\delta^{13} \mathrm{C}$. $(\mathrm{a}, \mathrm{b})$ The interparticle porosity is first cemented by nonluminescent isopachous fibrous cement (IFC), followed by C2. Under CL, $\mathrm{C} 1$ is nonluminescent and occasionally displays several thin yellow bands, whereas C2 shows red luminescence. Sample from $5885.92 \mathrm{~m}$, well S106. (c, d) Pore space is mainly filled by nonluminescent C3, and C4, exhibiting a bright orange luminescent zoned CL pattern, continued growth on C3 crystals and the filling of the remaining space. Sample from $5838.00 \mathrm{~m}$, well T751. (e, f) Dissolution pores are sequentially filled by $\mathrm{C} 1-\mathrm{C} 5$ cement. C 5 exhibits brown dull luminescence. Some corrosion of calcite C 5 and oil input are detectable. Sample from $5838.00 \mathrm{~m}$, well T751.

sands, silts, marls, and breccias (Figure 6(d)); and the other was characterized by calcite cement and marl, with little detrital quartz sand (Figure 6(e)). During drilling, lost cores, bit drops, and lost circulation occurred in nine wells (e.g., wells S106 and S110). The above observations suggest the development of large cavities in these carbonates.
Based on core measurements, the total fracture frequency is 8 fractures per meter, whereas the open fracture frequency is only 1.6 fractures per meter. Therefore, approximately $80 \%$ of the observed fractures are infilled, which limits fracture connectivity. Most of the fractures are partially or completely occluded by green marl (Figure 6(f)). 


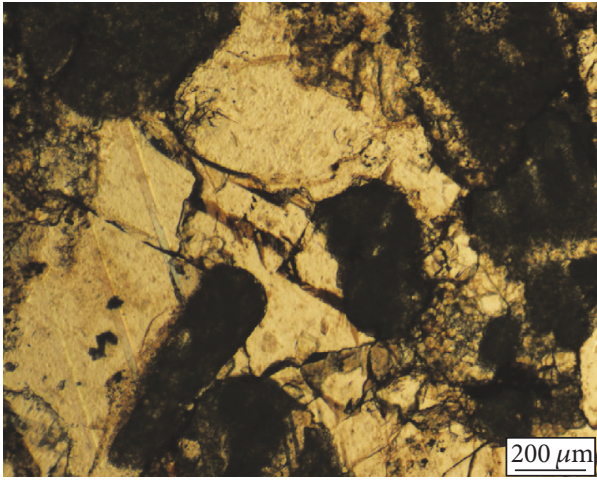

(a)

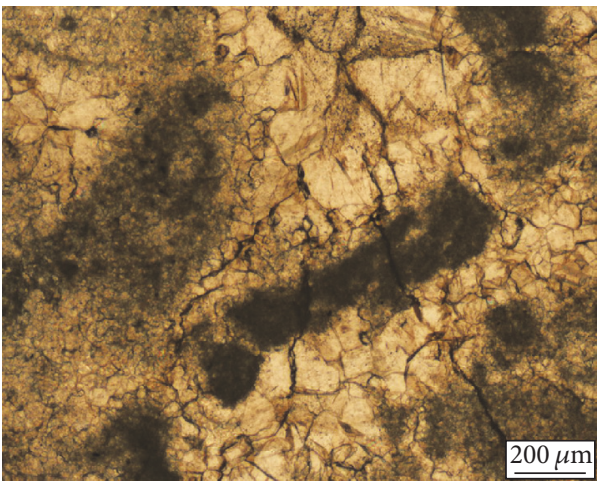

(c)

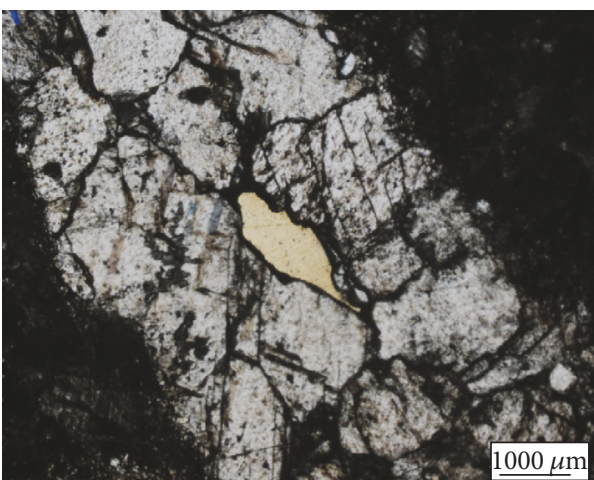

(e)

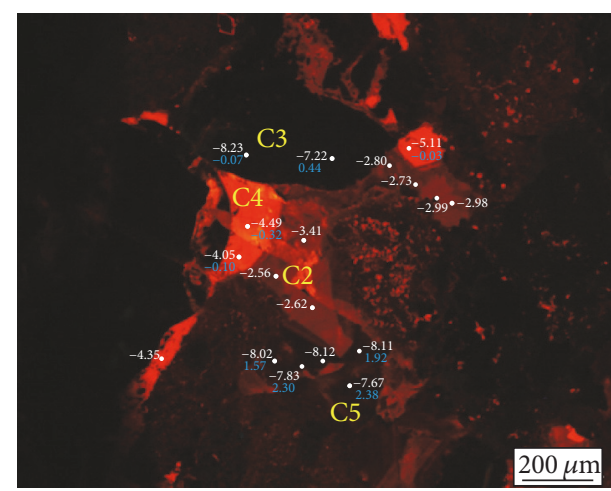

(b)

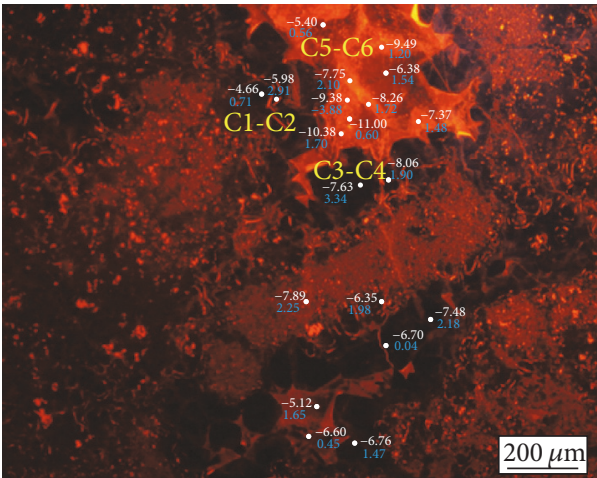

(d)

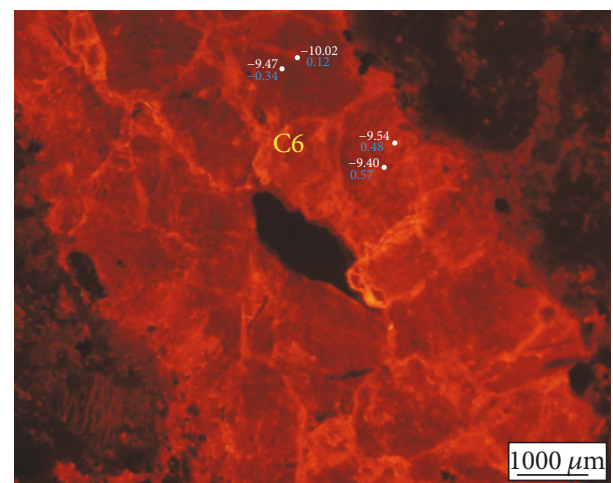

(f)

FIGURE 5: Photomicrograph pairs in transmitted light (a, c, and e) and cathodoluminescence (b, d, and f) of samples illustrating the main cement features in the Lianglitag Fm. carbonate rocks. The white circle is the position of the SIM analysis point; the white digit is $\delta^{18} \mathrm{O}$ and the blue digit is $\delta^{13} \mathrm{C}$. (a, b) The dissolution pore is mainly cemented by $\mathrm{C} 2-\mathrm{C} 5$, and $\mathrm{C} 2$ is obviously cut by $\mathrm{C} 3$, indicating that it predated the formation. Sample from $5893.10 \mathrm{~m}$, well T738. (c, d) The dissolution pore is cemented by C1-C6. Sample from 5779.36 m, well T904. (e, f) C6 with red luminescence fills the pore and the remaining effective pore is seen. Sample from $6089.9 \mathrm{~m}$, well S110.

\subsection{Isotope Geochemistry and Fluid Inclusion Microthermometry}

4.2.1. In Situ Carbon and Oxygen Isotopes by SIMS. Carbon and oxygen isotopic data for pore-filling calcite cement from SIMS measurement were presented in Figure 7 and listed in Table 1.

C1. This calcite has $\delta^{18} \mathrm{O}$ values ranging from -3.62 to $-0.10 \%$ o $\mathrm{VPDB}$, with a mean value of $-1.32 \%$ o $(n=23)$. The range of $\delta^{13} \mathrm{C}$ values on $\mathrm{C} 1$ fluctuates from $1.44 \%$ to $4.50 \%$ VPDB, with a mean value of $3.72 \%$ VPDB $(n=16)$.

C2. Compared with $\mathrm{C} 1$, the $\delta^{18} \mathrm{O}$ values of $\mathrm{C} 2$ are more negative, ranging between -6.35 and $-2.56 \%$ VPDB, with a mean value of $-4.24 \%$ VPDB $(n=15)$. The range of $\delta^{13} \mathrm{C}$ values on $\mathrm{C} 2$ fluctuates from -0.91 to $3.75 \%$, with a mean value of $1.55 \%$ o $\operatorname{VPDB}(n=11)$.

C3. The oxygen isotope values on $\mathrm{C} 3$ are more negative than $\mathrm{C} 2$, ranging from -8.45 to $-6.50 \%$ VPDB, with a mean value 
TABLE 1: Carbon and oxygen isotopic data of different stages of pore-filling calcite cement by in situ SIMS of Lianglitag Formation carbonates in the Tahe Oilfield.

\begin{tabular}{|c|c|c|c|c|c|c|c|}
\hline Well & Number & $\begin{array}{l}\text { Depth } \\
(\mathrm{m})\end{array}$ & Stage & $\begin{array}{c}\delta^{18} \mathrm{O} \\
\text { (\%o VPDB) }\end{array}$ & $2 \mathrm{SE}$ & $\begin{array}{c}\delta^{13} \mathrm{C} \\
\text { (\%o VPDB) }\end{array}$ & $2 \mathrm{SE}$ \\
\hline S106 & 1 & 5885.92 & $\mathrm{C} 1$ & -0.77 & 0.33 & 4.08 & 0.34 \\
\hline S106 & 2 & 5885.92 & $\mathrm{C} 1$ & -0.75 & 0.26 & 4.50 & 0.43 \\
\hline S106 & 3 & 5885.92 & $\mathrm{C} 1$ & -1.39 & 0.35 & 3.72 & 0.49 \\
\hline S106 & 4 & 5885.92 & $\mathrm{C} 1$ & -0.58 & 0.30 & 3.69 & 0.48 \\
\hline S106 & 5 & 5885.92 & $\mathrm{C} 1$ & -1.62 & 0.34 & - & - \\
\hline S106 & 6 & 5885.92 & $\mathrm{C} 1$ & -0.94 & 0.33 & - & - \\
\hline S106 & 7 & 5885.92 & $\mathrm{C} 1$ & -0.73 & 0.22 & - & - \\
\hline S106 & 8 & 5885.92 & $\mathrm{C} 1$ & -1.05 & 0.25 & - & - \\
\hline S106 & 9 & 5885.92 & $\mathrm{C} 1$ & -0.10 & 0.34 & - & - \\
\hline S106 & 10 & 5885.92 & $\mathrm{C} 1$ & -0.94 & 0.28 & - & - \\
\hline S106 & 11 & 5885.92 & $\mathrm{C} 1$ & -1.76 & 0.33 & 4.10 & 0.43 \\
\hline S106 & 12 & 5885.92 & $\mathrm{C} 1$ & -1.18 & 0.32 & 4.34 & 0.45 \\
\hline S106 & 13 & 5885.92 & $\mathrm{C} 1$ & -1.36 & 0.43 & 3.50 & 0.56 \\
\hline S106 & 14 & 5885.92 & $\mathrm{C} 1$ & -0.86 & 0.31 & 3.35 & 0.45 \\
\hline S106 & 15 & 5885.92 & $\mathrm{C} 1$ & -1.44 & 0.29 & 3.72 & 0.44 \\
\hline S106 & 16 & 5885.92 & $\mathrm{C} 1$ & -1.34 & 0.21 & 2.98 & 0.55 \\
\hline S106 & 17 & 5885.92 & $\mathrm{C} 1$ & -1.29 & 0.29 & 4.02 & 0.49 \\
\hline S106 & 18 & 5885.92 & $\mathrm{C} 1$ & -1.39 & 0.32 & 4.02 & 0.45 \\
\hline S106 & 19 & 5885.92 & $\mathrm{C} 2$ & -5.03 & 0.34 & 2.47 & 0.39 \\
\hline S106 & 20 & 5885.92 & C2 & -5.07 & 0.35 & 1.58 & 0.37 \\
\hline S106 & 21 & 5885.92 & $\mathrm{C} 2$ & -5.56 & 0.23 & 2.72 & 0.39 \\
\hline S106 & 22 & 5885.92 & $\mathrm{C} 2$ & -5.28 & 0.26 & 2.13 & 0.45 \\
\hline S106 & 23 & 5885.92 & $\mathrm{C} 1$ & -1.39 & 0.33 & 3.91 & 0.48 \\
\hline S106 & 24 & 5885.92 & $\mathrm{C} 1$ & -0.81 & 0.29 & 4.04 & 0.43 \\
\hline S106 & 25 & 5885.92 & $\mathrm{C} 1$ & -2.32 & 0.38 & 1.44 & 0.39 \\
\hline S110 & 1 & 6089.90 & C6 & -9.43 & 0.35 & 0.92 & 0.44 \\
\hline S110 & 2 & 6089.90 & C6 & -9.16 & 0.30 & -0.88 & 0.70 \\
\hline S110 & 3 & 6089.90 & C6 & -9.69 & 0.29 & 0.13 & 0.42 \\
\hline S110 & 4 & 6089.90 & C6 & -9.14 & 0.28 & - & - \\
\hline S110 & 5 & 6089.90 & C6 & -9.19 & 0.29 & 0.91 & 0.39 \\
\hline S110 & 6 & 6089.90 & C6 & -9.47 & 0.43 & -0.34 & 0.48 \\
\hline S110 & 7 & 6089.90 & C6 & -10.02 & 0.35 & -0.12 & 0.42 \\
\hline S110 & 8 & 6089.90 & C6 & -9.54 & 0.26 & 0.48 & 0.36 \\
\hline S110 & 9 & 6089.90 & C6 & -9.40 & 0.26 & 0.57 & 0.48 \\
\hline T738 & 1 & 5893.10 & $\mathrm{C} 2$ & -2.56 & 0.19 & - & - \\
\hline T738 & 2 & 5893.10 & C3 & -8.23 & 0.25 & -0.07 & 0.58 \\
\hline T738 & 3 & 5893.10 & C3 & -7.22 & 0.30 & 0.12 & 0.44 \\
\hline T738 & 4 & 5893.10 & $\mathrm{C} 2$ & -2.98 & 0.22 & - & - \\
\hline T738 & 5 & 5893.10 & $\mathrm{C} 2$ & -2.62 & 0.30 & - & - \\
\hline T738 & 6 & 5893.10 & C5 & -8.02 & 0.14 & 1.57 & 0.53 \\
\hline T738 & 7 & 5893.10 & C5 & -8.12 & 0.27 & - & - \\
\hline T738 & 8 & 5893.10 & C5 & -7.67 & 0.22 & 2.38 & 0.44 \\
\hline T738 & 9 & 5893.10 & $\mathrm{C} 2$ & -3.41 & 0.25 & - & - \\
\hline T738 & 10 & 5893.10 & $\mathrm{C} 4$ & -4.05 & 0.20 & -0.10 & 0.58 \\
\hline T738 & 11 & 5893.10 & $\mathrm{C} 4$ & -4.49 & 0.22 & -0.32 & 0.54 \\
\hline T738 & 12 & 5893.10 & C5 & -7.83 & 0.27 & 2.30 & 0.44 \\
\hline T738 & 13 & 5893.10 & C5 & -8.11 & 0.30 & 1.92 & 0.49 \\
\hline
\end{tabular}


TABle 1: Continued.

\begin{tabular}{|c|c|c|c|c|c|c|c|}
\hline Well & Number & $\begin{array}{c}\text { Depth } \\
(\mathrm{m})\end{array}$ & Stage & $\begin{array}{c}\delta^{18} \mathrm{O} \\
(\% \text { VPDB })\end{array}$ & 2SE & $\begin{array}{c}\delta^{13} \mathrm{C} \\
(\% \circ \mathrm{VPDB})\end{array}$ & 2SE \\
\hline T738 & 14 & 5893.10 & $\mathrm{C} 2$ & -2.99 & 0.28 & - & - \\
\hline T738 & 15 & 5893.10 & $\mathrm{C} 2$ & -2.73 & 0.21 & - & - \\
\hline T738 & 16 & 5893.10 & $\mathrm{C} 2$ & -2.80 & 0.25 & - & - \\
\hline T738 & 17 & 5893.10 & $\mathrm{C} 4$ & -5.11 & 0.22 & -0.03 & 0.31 \\
\hline T738 & 18 & 5893.10 & $\mathrm{C} 4$ & -4.35 & 0.27 & - & - \\
\hline T751 & 1 & 5838.00 & $\mathrm{C} 3$ & -7.10 & 0.26 & 2.75 & 0.62 \\
\hline T751 & 2 & 5838.00 & C3 & -6.50 & 0.28 & 3.33 & 0.44 \\
\hline T751 & 3 & 5838.00 & C3 & -8.14 & 0.28 & 1.61 & 0.45 \\
\hline T751 & 4 & 5838.00 & $\mathrm{C} 4$ & -2.83 & 0.35 & 2.05 & 0.47 \\
\hline T751 & 5 & 5838.00 & $\mathrm{C} 4$ & -3.42 & 0.34 & 2.52 & 0.51 \\
\hline T751 & 6 & 5838.00 & $\mathrm{C} 1$ & -3.62 & 0.38 & - & - \\
\hline T751 & 7 & 5838.00 & $\mathrm{C} 4$ & -4.07 & 0.30 & 2.80 & 0.50 \\
\hline T751 & 8 & 5838.00 & $\mathrm{C} 4$ & -2.29 & 0.37 & - & - \\
\hline T751 & 9 & 5838.00 & $\mathrm{C} 3$ & -7.82 & 0.34 & 3.17 & 0.51 \\
\hline T751 & 10 & 5838.00 & Matrix & -5.33 & 0.41 & 3.35 & 0.67 \\
\hline T751 & 11 & 5838.00 & $\mathrm{C} 3$ & -7.12 & 0.22 & 3.66 & 0.28 \\
\hline T751 & 12 & 5838.00 & $\mathrm{C} 3$ & -7.88 & 0.34 & 4.02 & 0.37 \\
\hline T751 & 13 & 5838.00 & $\mathrm{C} 4$ & -5.07 & 0.34 & 4.9 & 0.57 \\
\hline T751 & 14 & 5838.00 & C3 & -8.45 & 0.38 & 2.59 & 0.51 \\
\hline T751 & 15 & 5838.00 & $\mathrm{C} 3$ & -7.60 & 0.29 & 4.07 & 0.47 \\
\hline T751 & 16 & 5838.00 & $\mathrm{C} 3$ & -7.09 & 0.24 & 3.87 & 0.48 \\
\hline T751 & 17 & 5838.00 & $\mathrm{C} 4$ & -5.37 & 0.41 & 3.75 & 0.58 \\
\hline T751 & 18 & 5838.00 & $\mathrm{C} 4$ & -3.51 & 0.33 & 3.07 & 0.55 \\
\hline T751 & 19 & 5838.00 & $\mathrm{C} 3$ & -8.76 & 0.34 & 1.44 & 0.59 \\
\hline T751 & 20 & 5838.00 & $\mathrm{C} 4$ & -3.50 & 0.29 & 3.49 & 0.24 \\
\hline T751 & 21 & 5838.00 & C3 & -8.18 & 0.22 & - & - \\
\hline T751 & 22 & 5838.00 & $\mathrm{C} 2$ & -5.55 & 0.23 & 3.75 & 0.28 \\
\hline T751 & 23 & 5838.00 & $\mathrm{C} 1$ & -2.68 & 0.23 & 4.04 & 0.32 \\
\hline Т904 & 1 & 5779.36 & C6 & -9.38 & 0.27 & -3.88 & 0.32 \\
\hline T904 & 2 & 5779.36 & C6 & -10.38 & 0.26 & 1.70 & 0.44 \\
\hline T904 & 3 & 5779.36 & C5 & -8.26 & 0.24 & 1.72 & 0.43 \\
\hline Т904 & 4 & 5779.36 & $\mathrm{C} 5$ & -7.75 & 0.28 & 2.10 & 0.43 \\
\hline Т904 & 5 & 5779.36 & C6 & -9.49 & 0.27 & 1.20 & 0.48 \\
\hline T904 & 6 & 5779.36 & C5 & -7.37 & 0.22 & 1.48 & 0.42 \\
\hline T904 & 7 & 5779.36 & $\mathrm{C} 3$ & -8.06 & 0.27 & 1.90 & 0.53 \\
\hline T904 & 8 & 5779.36 & C3 & -7.63 & 0.19 & 3.34 & 0.62 \\
\hline Т904 & 9 & 5779.36 & $\mathrm{C} 2$ & -4.66 & 0.28 & 0.71 & 0.51 \\
\hline T904 & 10 & 5779.36 & $\mathrm{C} 2$ & -5.98 & 0.39 & 2.91 & 0.59 \\
\hline T904 & 11 & 5779.36 & C5 & -6.38 & 0.28 & 1.54 & 0.47 \\
\hline T904 & 12 & 5779.36 & C6 & -11.00 & 0.38 & 0.60 & 0.46 \\
\hline Т904 & 13 & 5779.36 & C5 & -5.40 & 0.20 & 0.56 & 0.47 \\
\hline Т904 & 14 & 5779.36 & Matrix & -7.89 & 0.36 & 2.25 & 0.45 \\
\hline Т904 & 15 & 5779.36 & $\mathrm{C} 2$ & -6.35 & 0.32 & 1.98 & 0.48 \\
\hline Т904 & 16 & 5779.36 & $\mathrm{C} 3$ & -7.48 & 0.34 & 2.18 & 0.46 \\
\hline Т904 & 17 & 5779.36 & $\mathrm{C} 3$ & -6.70 & 0.25 & 0.04 & 0.56 \\
\hline T904 & 18 & 5779.36 & C5 & -5.12 & 0.29 & 1.65 & 0.51 \\
\hline T904 & 19 & 5779.36 & C5 & -6.60 & 0.33 & 0.45 & 0.41 \\
\hline T904 & 20 & 5779.36 & $\mathrm{C} 3$ & -6.76 & 0.24 & 1.47 & 0.58 \\
\hline
\end{tabular}




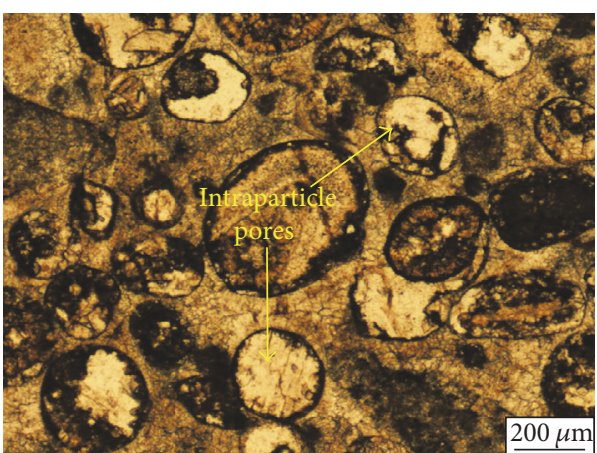

(a)

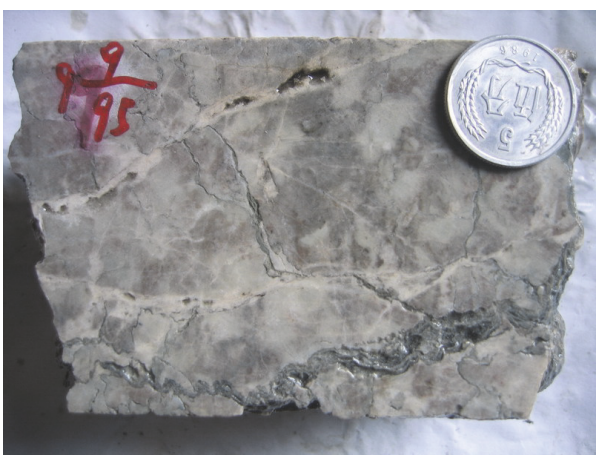

(c)

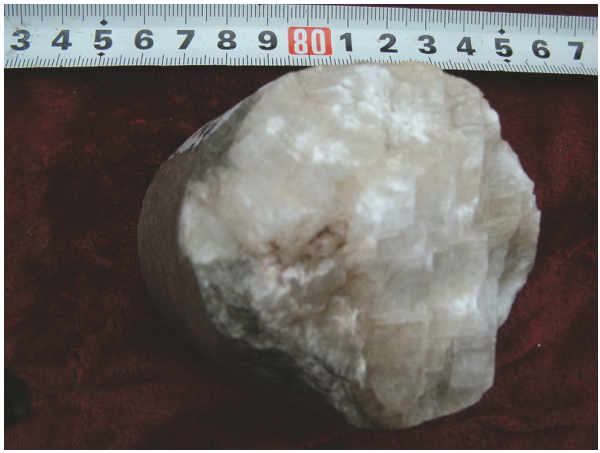

(e)

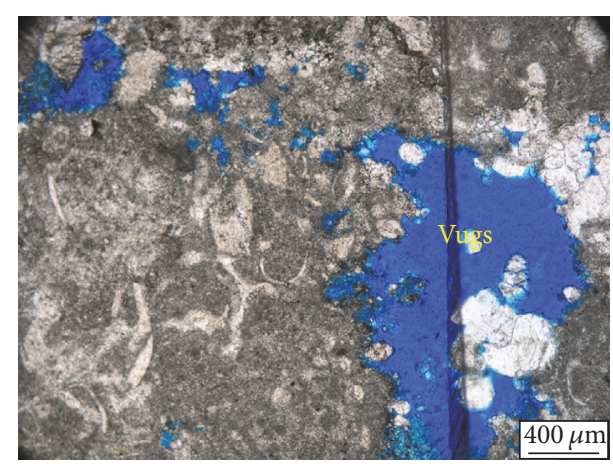

(b)

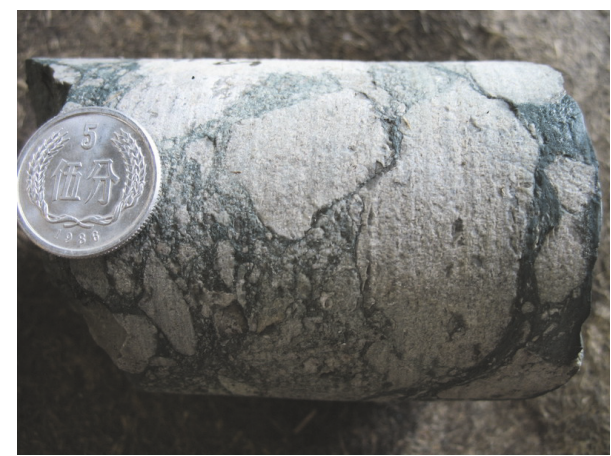

(d)

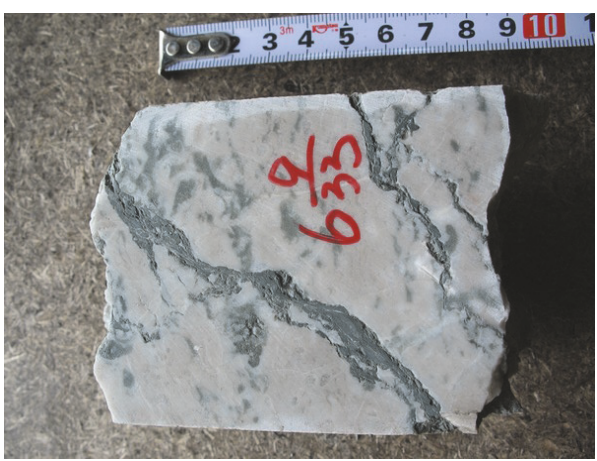

(f)

FIGURE 6: Photographs showing typical diagenetic features in the carbonate rocks of the Lianglitag Fm. (a) Early intragranular dissolution of carbonate minerals developed (most of them were filled during diagenesis), well S111, depth $6108.7 \mathrm{~m}$. (b) Non-fabric-selective dissolution pores and vugs developed, well AD4, depth $6463.42 \mathrm{~m}$. (c) Dissolution vug developed along fractures. Sample from $5794.1 \mathrm{~m}$, well T904. (d) Cavern breccias developed in the Tahe Oilfield, well TH204, depth $5469.2 \mathrm{~m}$. (e) Giant crystal calcite filling the cave. Sample from $6245.95 \mathrm{~m}$, well S116. (f) Fracture filled by green marl in the Tahe Oilfield, well T904, depth $5773.21 \mathrm{~m}$.

of $-7.59 \%$ o $\operatorname{VPDB}(n=18)$, and the $\delta^{13} \mathrm{C}$ values are from -0.07 to $4.07 \%$ VPDB, with a mean value of $2.32 \%$ VPDB $(n=17)$.

C4. The $\delta^{18} \mathrm{O}$ values are typically $3 \%$ higher than those of $\mathrm{C} 3$, lying between -5.37 and $-2.29 \%$ VPDB, with a mean value of $-4.01 \%$ VPDB $(n=12)$, and the $\delta^{13} \mathrm{C}$ values on C4 are close to those of $\mathrm{C} 3$, ranging from -0.32 to $4.90 \%$ VPDB, with a mean value of $2.21 \%$ o $\operatorname{VPDB}(n=10)$.

C5. C5 shows more negative $\delta^{18} \mathrm{O}_{\mathrm{VPDB}}$ values $(-8.26 \%$ o to $-5.12 \%$ o VPDB) than those of $\mathrm{C} 4$, with a mean value of
$-7.14 \%$ VPDB $(n=11)$, and similar $\delta^{13} \mathrm{C}_{\mathrm{VPDB}}$ values $(0.45 \%$ o to $2.38 \%$ o VPDB).

C6. C6 displays low $\delta^{18} \mathrm{O}$ values ranging from -11.00 to $-9.14 \%$ VPDB, with a mean value of $-9.64 \% \operatorname{VPDB}(n=13)$, and $\delta^{13} \mathrm{C}$ values ranging from -0.88 to $1.70 \% \operatorname{VPDB}(n=12)$, except one low value $(-3.88 \%)$ of VPDB.

4.2.2. Traditional Carbon and Oxygen Isotopes. The micrite ranges between -8.05 and $-3.78 \%$ VPDB for $\delta^{18} \mathrm{O}$ (mean $-6.53 \%$ VPDB, $n=14$ ) and between $0.56 \%$ and $2.48 \%$ VPDB for $\delta^{13} \mathrm{C}$ (mean $1.92 \%$ VPDB, $n=14$ ). The oxygen 


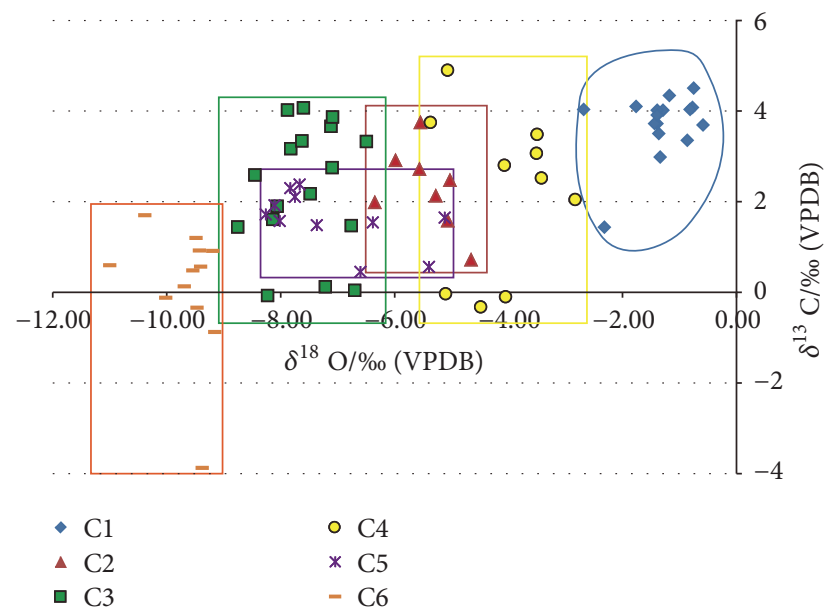

Figure 7: $\delta^{13} \mathrm{C}$ and $\delta^{18} \mathrm{O}$ values of different stages of pore-filling calcite cement by in situ SIMS.

isotopic compositions of grainstone are close to those of micrite, ranging from -8.45 to $-3.23 \% \mathrm{VPDB}$ (mean $-5.98 \%$ o VPDB, $n=20$ ), and the carbon isotopic compositions of grainstone varies from $-0.64 \%$ to $2.27 \%$ VPDB (mean $0.97 \%$ o VPDB, $n=20$ ). Fracture- and cave-filling calcite cement have $\delta^{18} \mathrm{O}_{\mathrm{VPDB}}$ values ranging from $-11.02 \%$ to $-8.16 \%$ VPDB (mean $-9.71 \% \mathrm{VPDB}, n=10$ ) and $\delta^{13} \mathrm{C}_{\mathrm{VPDB}}$ values ranging from $-2.16 \%$ to $3.16 \%$ VPDB (mean $-0.02 \%$ VPDB, $n=$ 10), respectively. The analytical results are listed in Table 2 and shown in Figure 8.

4.2.3. Strontium Isotopes. The analytical results are listed in Table 2 and shown in Figure 9(a). The micrite spans a broad range from 0.709005 to 0.711927 (mean value of 0.710418 , $n=3)$. The grainstone yields ${ }^{87} \mathrm{Sr} /{ }^{86} \mathrm{Sr}$ ratios of 0.708136 to 0.709119 (mean value of $0.708659, n=12$ ). The fracture and vug fillings present much higher ${ }^{87} \mathrm{Sr} /{ }^{86} \mathrm{Sr}$ ratios, ranging from 0.709103 to 0.712863 (mean value of $0.710377, n=10$ ).

4.2.4. Fluid Inclusions (FI). 25 doubly polished detachable wafers of calcite samples were prepared and analyzed for FI. Petrography, both transmitted light and UV fluorescence, was performed on doubly polished wafers to identify inclusion types for further analysis and to determine their relationship to the host minerals. The large and/or elongate inclusions were disregarded, which could mean stretching and resetting since their formation [41].

The fluid inclusion homogenization temperatures $T_{h}$ and salinity (weight percent of $\mathrm{NaCl}$ equivalent) results of the cementing phases are shown in Figure 10. $\mathrm{Cl}$ is inclusion poor; therefore, no microthermometry was conducted in this cement.

C2 contains a few fluid inclusions, and the shape of the fluid inclusion is much more regular. The homogenization temperatures $\left(T_{h}\right)$ range from $72^{\circ} \mathrm{C}$ to $91^{\circ} \mathrm{C}$. The salinity, derived from the final melting temperature of ice using the equation from Bodnar [40], ranges from $4.96 \mathrm{wt} \%$ to $10.73 \mathrm{wt} \% \mathrm{NaCl}$ equiv.

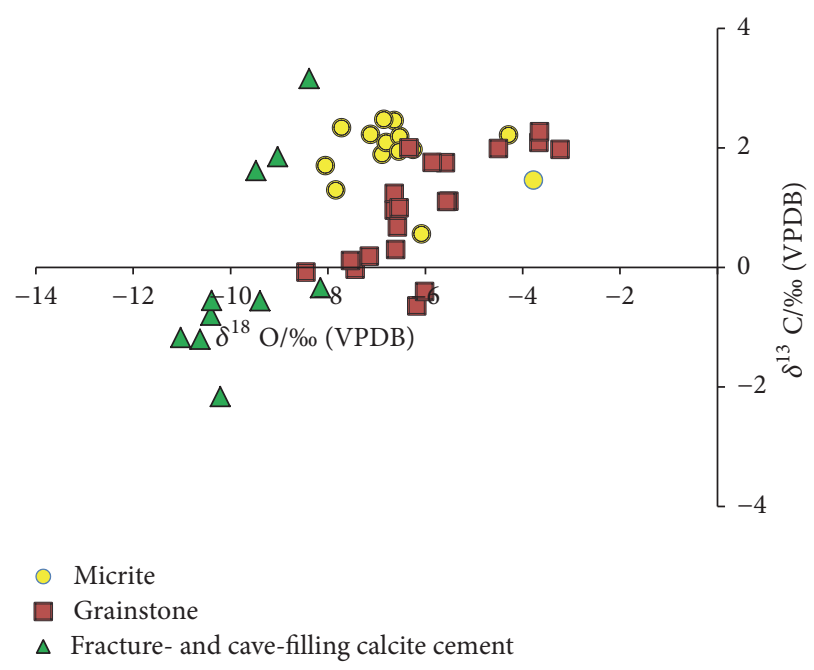

Figure 8: $\delta^{13} \mathrm{C}$ and $\delta^{18} \mathrm{O}$ values of host rocks and fracture- and cavefilling calcite cement by conventional methods.

Fluid inclusions in C3 are more abundant and mainly occur as single-phase aqueous inclusions with sizes $<4 \mu \mathrm{m}$ in general, which are too small to be measured.

The characteristics of inclusions in C4 are very similar to those of $\mathrm{C} 2$, with fewer numbers and the shape of fluid inclusion being more regular. $T_{h}$ is less than $90^{\circ} \mathrm{C}$, and salinity is moderate, ranging from $6.45 \mathrm{wt} \%$ to $9.98 \mathrm{wt} \% \mathrm{NaCl}$ equiv.

C5 contains abundant aqueous fluid inclusions, sizes from 3 to $15 \mu \mathrm{m}$, and a vapor-to-liquid ratio of $<15 \%$ in general. C5 shows a wide range of $T_{h}$ varying from $91^{\circ} \mathrm{C}$ to $129^{\circ} \mathrm{C}(n=$ 58). Water salinities at the time of $\mathrm{C} 5$ are variable, ranging from $0.71 \mathrm{wt} \%$ to $23.18 \mathrm{wt} \% \mathrm{NaCl}$ equiv. ( $n=58$ ). Oil-filled fluid inclusions were observed and showed yellow or blue UV fluorescence.

Aqueous fluid inclusions in calcite cement $\mathrm{C} 6$ have a vapor-to-liquid ratio of $<15 \%$ and sizes of 4 to $12 \mu \mathrm{m}$. The average homogenization temperature is high, ranging from $132.6^{\circ} \mathrm{C}$ to $200^{\circ} \mathrm{C}$. Note that $\mathrm{C} 6$ with relatively high temperatures has relatively low-salinity values, less than $10.61 \mathrm{wt} \%$ $\mathrm{NaCl}$ equiv. Oil inclusions were observed with blue-white UV fluorescence emission colors.

\section{Discussion}

\subsection{Origin of Digenetic Fluids}

5.1.1. Stable Isotopes and Fluid Inclusion Constraints on Fluids. The combination of stable isotopic components and fluid inclusions can be used to estimate the formation temperature of diagenetic cement, which can further refine the diagenetic sequences and define the fluid properties.

Fibrous isopachous calcites are considered to be early marine cement that formed in the marine phreatic zone [42]. Therefore, $\mathrm{Cl}$ in this study formed in the early marine diagenesis environment. One type of blocky calcite cement surrounding bioclasts shows nonluminescence with several thin yellow bands (Figures 4(a) and 4(b)) based on similar 
TABLE 2: Carbon, oxygen, and strontium isotopic data of host rocks and fracture- and vug-filling calcite cements by conventional methods of Lianglitag Formation carbonates in the Tahe Oilfield.

\begin{tabular}{|c|c|c|c|c|c|c|}
\hline Well & $\begin{array}{c}\text { Depth } \\
(\mathrm{m})\end{array}$ & Sample type & Host lithology & $\begin{array}{c}\delta^{18} \mathrm{O} \\
(\% \text { VPDB })\end{array}$ & $\begin{array}{c}\delta^{13} \mathrm{C} \\
(\% \text { VPDB })\end{array}$ & $\mathrm{Sr}^{87} / \mathrm{Sr}^{86}$ \\
\hline S79 & 5499.96 & Whole rock & Micritic limestones & -3.777 & 1.463 & - \\
\hline T443 & 5515.90 & Whole rock & Micritic limestones & -7.837 & 1.296 & - \\
\hline T751 & 5838 & Whole rock & Micritic limestones & -6.639 & 2.457 & - \\
\hline T904 & 5776 & Whole rock & Micritic limestones & -6.885 & 1.892 & - \\
\hline T751 & 5840.20 & Whole rock & Micritic limestones & -7.125 & 2.229 & $0.709005^{*}$ \\
\hline T751 & 5835.70 & Whole rock & Micritic limestones & -7.718 & 2.337 & - \\
\hline T751 & 5776 & Whole rock & Micritic limestones & -6.801 & 2.091 & $0.710323^{*}$ \\
\hline T751 & 5772.7 & Whole rock & Micritic limestones & -6.523 & 2.194 & - \\
\hline S106 & 5884.14 & Whole rock & Micritic limestones & -4.288 & 2.215 & $0.710756^{*}$ \\
\hline T751 & 5833.9 & Whole rock & Micritic limestones & -6.85 & 2.48 & - \\
\hline T705 & 5657.95 & Whole rock & Micritic limestones & -6.08 & 0.563 & $0.711927^{*}$ \\
\hline T904 & 5803 & Whole rock & Micritic limestones & -6.542 & 1.944 & - \\
\hline T904 & 5792.54 & Whole rock & Micritic limestones & -8.05 & 1.704 & - \\
\hline T904 & 5779.36 & Whole rock & Micritic limestones & -6.247 & 1.975 & - \\
\hline S106 & 5934.86 & Whole rock & Grainstone & -4.493 & 1.988 & \\
\hline S110 & 6088.43 & Whole rock & Grainstone & -8.448 & -0.078 & $0.708904^{*}$ \\
\hline S99 & 5925.06 & Whole rock & Grainstone & -6.335 & 1.999 & - \\
\hline S110 & 6089.9 & Whole rock & Grainstone & -7.44 & -0.028 & $0.709088^{*}$ \\
\hline S107 & 6186.86 & Whole rock & Grainstone & -6.635 & 1.238 & - \\
\hline S107 & 6188.9 & Whole rock & Sparry bioclastic limestone & -6.635 & 0.959 & - \\
\hline T705 & 5638.99 & Whole rock & Sparry oolitic limestone & -6.171 & -0.643 & - \\
\hline T705 & 5648.6 & Whole rock & Grainstone & -6.607 & 0.3 & $0.708659^{*}$ \\
\hline T738 & 5883.9 & Whole rock & Grainstone & -6.535 & 0.996 & - \\
\hline T114 & 6299.39 & Whole rock & Grainstone & -3.23 & 1.977 & $0.70856^{*}$ \\
\hline S107 & 6230.33 & Whole rock & Grainstone & -5.51 & 1.107 & - \\
\hline S110 & 6086.52 & Whole rock & Grainstone & -7.149 & 0.19 & $0.709119^{*}$ \\
\hline S110 & 6083.91 & Whole rock & Grainstone & -7.532 & 0.115 & $0.708919^{*}$ \\
\hline TP5 & 6158.68 & Whole rock & Grainstone & -6.568 & 0.679 & - \\
\hline T114 & 6304.17 & Whole rock & Grainstone & -3.664 & 2.091 & $0.708596^{*}$ \\
\hline S106 & 5885.92 & Whole rock & Sparry bioclastic limestone & -3.653 & 2.268 & $0.708353^{*}$ \\
\hline T705 & 5638.3 & Whole rock & Bioclastic limestone & -6.01 & -0.403 & $0.708261^{*}$ \\
\hline S111 & 6108.7 & Whole rock & Sparry bioclastic limestone & -5.582 & 1.75 & - \\
\hline S111 & 6105.89 & Whole rock & Sparry bioclastic limestone & -5.86 & 1.757 & $0.708202^{*}$ \\
\hline S111 & 6104.96 & Whole rock & Sparry bioclastic limestone & -5.558 & 1.105 & $0.708136^{*}$ \\
\hline S106 & 5885.92 & Fracture-filling calcite cements & Sparry bioclastic limestone & -9.481 & 1.622 & 0.711119 \\
\hline S110 & 6098.3 & Cavern-filling calcite cements & Marly limestone & -11.023 & -1.175 & 0.712863 \\
\hline S110 & 6096.61 & Vug-filling calcite cements & Micritic oolitic limestone & -10.624 & -1.201 & - \\
\hline S110 & 6089.9 & Cavern-filling calcite cements & Grainstone & -10.408 & -0.799 & - \\
\hline S110 & 6083.91 & Fracture-filling calcite cements & Grainstone & -9.393 & -0.559 & - \\
\hline T79 & 5515.75 & Cavern-filling calcite cements & Siltstone & -10.213 & -2.159 & - \\
\hline T79 & 5509.3 & Cavern-filling calcite cements & Siltstone & -8.155 & -0.341 & - \\
\hline T204 & 5466.19 & Cavern-filling calcite cements & Breccia & -10.389 & -0.554 & - \\
\hline T751 & 5840.20 & Vug-filling calcite cements & Micritic limestones & -8.383 & 3.16 & 0.709103 \\
\hline T904 & 5779.36 & Vug-filling calcite cements & Micritic limestones & -9.033 & 1.854 & - \\
\hline
\end{tabular}

${ }^{*}$ After Liu et al. [23]. 


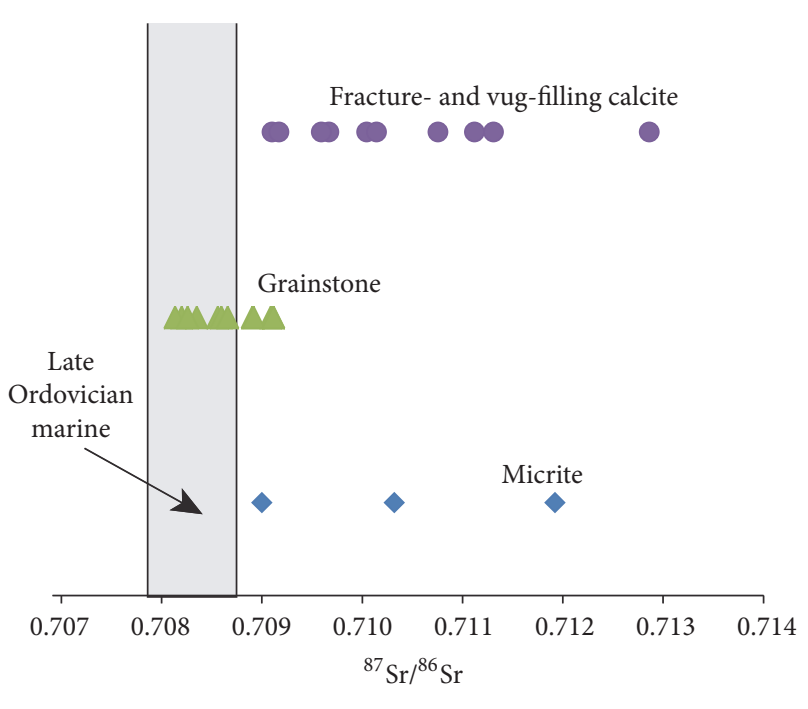

(a)

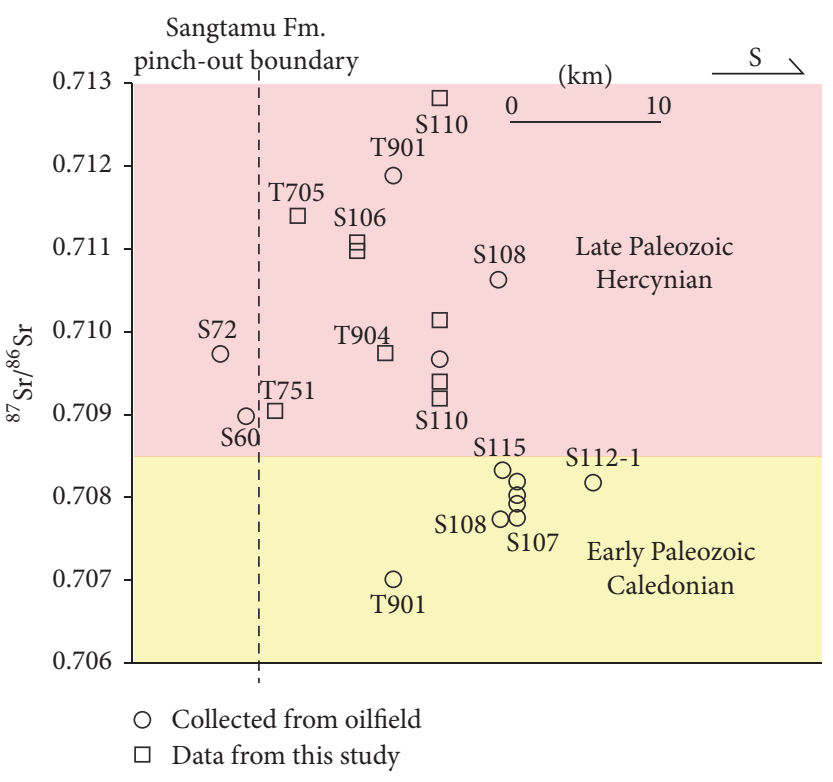

(b)

FIGURE 9: Characteristics of ${ }^{87} \mathrm{Sr} /{ }^{86} \mathrm{Sr}$ values from the Lianglitag Formation. (a) ${ }^{87} \mathrm{Sr} /{ }^{86} \mathrm{Sr}$ values of micrite, grainstone, and fractures and vug-filling calcite. (b) Distribution of ${ }^{87} \mathrm{Sr} /{ }^{86} \mathrm{Sr}$ values from different wells in plane.
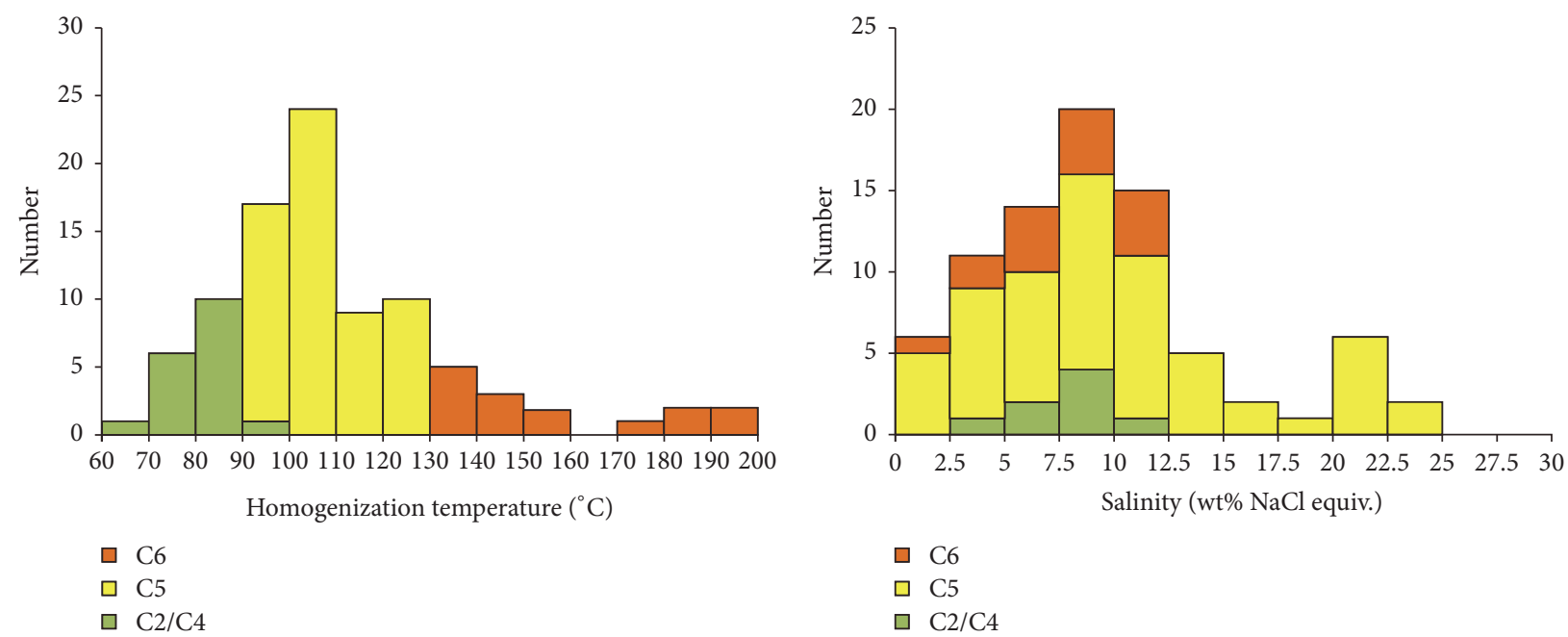

FIGURE 10: Histograms showing homogenization temperatures and salinities measured from fluid inclusions of different stages of pore-filling calcite cement.

$\delta^{18} \mathrm{O}$ values and $\delta^{13} \mathrm{C}$ values with fibrous isopachous calcites (C1) (Figure 7). Hence, this blocky calcite cement should precipitate in marine diagenesis environment as well. Shields et al. [43] have reported that $\delta^{18} \mathrm{O}$ values of $-6 \%$ to $-4 \%$ VPDB and $\delta^{13} \mathrm{C}$ of $-2 \%$ to $2 \%$ VPDB characterize the global marine carbonates carbon and oxygen isotope values during the Late Ordovician. Assuming that the Late Ordovician limestones originally had a temperature of $25^{\circ} \mathrm{C}$ for subtropical seawater $[44,45]$ and using the O'Neil et al. [46] calcite-water oxygen isotope fractionation equation, the $\delta^{18} \mathrm{O}$ value of the water present during the growth of $\mathrm{Cl}$ was between $-1.22 \%$ and $2.4 \%$ V-SMOW, higher than that of Late Ordovician seawater, that is -3 to $-6 \% \mathrm{~V}$ SMOW [43]. The slightly higher oxygen isotope values can be achieved by evaporation [47]. Therefore, the higher $\delta^{18} \mathrm{O}$ value suggests that evaporative concentration of seawater may have occurred during precipitation of $\mathrm{Cl}$. The higher $\delta^{18} \mathrm{O}$ value was mainly found in well S106, located at the southern part of the study area and characterized by deep slope facies (Figure 1(b)). Hence, environmental influence may be an alternative interpretation for oxygen isotopic changes in carbonate.

Compared with $\mathrm{C} 1$, the $\mathrm{C} 2$ shows slightly lower $\delta^{18} \mathrm{O}$ values ( -6.35 to $-2.56 \%$ VPDB; Figure 7$)$, and homogenization 
temperature $T_{h}$ from fluid inclusion study indicates that C2 with coarser crystal was formed during burial diagenesis at approximately $60-90^{\circ} \mathrm{C}$ (Figure 10 ).

C3 shows lower oxygen values compared with $\mathrm{C} 2$. The more negative $\delta^{18} \mathrm{O}$ values could be due either to precipitation at a higher temperature or to precipitation from waters with lower $\delta^{18} \mathrm{O}$ values [48, 49]. The single-phase aqueous fluid inclusion petrographic evidence, which indicates a capture temperature of less than $50^{\circ} \mathrm{C}$ [41], suggests that $\mathrm{C} 3$ probably was in meteoric origin. Previous studies have indicated that the Lianglitag Formation carbonates are affected by both Caledonian and Hercynian orogenic events [50-53]. Hence, C3 probably precipitated as a result of meteoric water diagenesis during Caledonian and/or Hercynian orogenic events.

Compared with $\mathrm{C} 3, \mathrm{C} 4$ shows much more positive $\delta^{18} \mathrm{O}$ values. Most of the $\delta^{18} \mathrm{O}$ values for $\mathrm{C} 4$ lie within the marine calcite ranges [43], indicating that C4 was most likely influenced by marine fluid. $T_{h}$ data from the fluid inclusions in $\mathrm{C} 4$ shows that it formed in temperatures up to $90^{\circ} \mathrm{C}$; hence, $\mathrm{C} 4$ probably precipitated during the shallow buried stage after the tectonic uplift. Melim et al. [54] also showed that the carbon and oxygen isotopes changed from negative to positive from the meteoric phreatic zone to a seawatershallow buried environment.

$\mathrm{C} 5$ has relatively negative $\delta^{18} \mathrm{O}_{\mathrm{VPDB}}$ values, with $\delta^{18} \mathrm{O}_{\mathrm{VPDB}}$ values ranging from -8.26 to $-5.12 \%$ vPDB. The high fluid inclusion temperatures $\left(91^{\circ} \mathrm{C}\right.$ to $\left.129^{\circ} \mathrm{C}\right)$ and wide range of salinity $(0 \sim 23.18 \mathrm{wt} \%)$ imply that C5 blocky spars may have precipitated during burial environment from the mixing of multiple sources of fluids.

The $\delta^{18} \mathrm{O}_{\mathrm{VPDB}}$ values of $\mathrm{C} 6$ are obviously negative and could be as low as $-11 \%$ VPDB. Fluid inclusions in C6 are shown to have relatively low salinities (from 0 to $10.61 \mathrm{wt} \%$ equiv. $\mathrm{NaCl}$ ) but highest homogenization temperatures (132.6 to $200^{\circ} \mathrm{C}$ ). Based on the $\delta^{18} \mathrm{O}$ values and measured $T_{h}$ temperatures, the isotopic signature of the parent fluid ranges from $5.57 \%$ o to $11.96 \%$ (SMOW). Combined with the regional burial history curve (Figure 3), the homogeneous temperature of $\mathrm{C6}$ exceeded the maximum burial experience of the strata. This type of calcite may have precipitated from a variety of processes: (1) the mixing of meteoric water with hydrothermal water, (2) thermochemical sulfate reduction, and (3) deeply recycled meteoric water. Hence, the high precipitation temperatures and relatively low salinity of the fluids indicate that C6 may have precipitated from meteoric water mixed with hydrothermal fluids. However, if this model applies, fluid inclusions with high temperatures are expected to have high salinities rather than low salinities, as was found in this area. The second possibility is that C6 with high homogenization temperatures and low salinities may have precipitated from thermochemical sulfate reduction (TSR) derived water $[15,55]$. TSR is redox reactions between hydrocarbon and dissolved sulfates in temperatures $>120^{\circ} \mathrm{C}$ [56-58]. TSR is well documented in Tazhong area [57, 59]. However, this proposal is discounted by the nonisotopically light carbon in both vug fillings and intergranular cement. Alternatively, deeply recycled meteoric water could have flowed down along faults to deep strata and thus became significantly heated. Subsequently, the heated meteoric water underwent upward migration, leading to the precipitation of hydrothermal calcite. This model of water flow was previously proposed by Qing and Mountjoy [60] to explain the variation of homogenization temperatures as well as the ${ }^{87} \mathrm{Sr} /{ }^{86} \mathrm{Sr}$ and $\delta^{18} \mathrm{O}$ values from saddle dolomite cement from the west towards the east in the Western Canada sedimentary basin as a result of tectonic thrusting and compression, sedimentary loading, and tectonic uplift on the western margin. The structural history of the Western Canada basin is broadly analogous to that of the Tahe area. Thus, it is possible for a similar model of water flow to have occurred in the study area as previously proposed by Li et al. [15], Jiang et al. [61], and Jiang et al. [62].

Different from $\delta^{18} \mathrm{O}, \delta^{13} \mathrm{C}$ is mainly controlled by carbon sources [63]. Most of the $\delta^{13} \mathrm{C}$ values from $\mathrm{C} 1$ to $\mathrm{C} 6$ lie between $-2 \%$ and $4 \%$ o (Figure 7 ), close to the $\delta^{13} \mathrm{C}$ range of contemporaneous seawater, indicating a local source of $\mathrm{C}$.

Compared with the $\delta^{18} \mathrm{O}$ and $\delta^{13} \mathrm{C}$ analysis results of matrix pore-filling calcite cement by the SIMS method, the $\delta^{18} \mathrm{O}$ and $\delta^{13} \mathrm{C}$ data of fracture- and cave-filling calcite cement obtained by traditional methods are more negative (Figure 8), most likely due to the results of karst, which had been discussed by Li et al. [15] in detail. Most of the oxygen isotopes of micrite and grainstone are obviously more negative than those of the Late Ordovian marine carbonate (from -6 to $-4 \%$ VPDB) [43], which indicates that the matrix limestone in the Lianglitag Formation is strongly affected by the late diagenetic fluid.

5.1.2. Strontium Isotopes. During the Late Ordovician, the carbonate strontium isotope composition of the global ocean ranged from 0.7078 to $0.7082[64,65]$. The seawater ${ }^{87} \mathrm{Sr} /{ }^{86} \mathrm{Sr}$ record is controlled by two main strontium fluxes and their isotopic compositions: the hydrothermal brines at midocean ridges (MOR flux), characterized by ${ }^{87} \mathrm{Sr} /{ }^{86} \mathrm{Sr}$ ratios being close to 0.703 , and the continental input (river flux), which has a modern global average ${ }^{87} \mathrm{Sr} /{ }^{86} \mathrm{Sr}$ ratio of 0.712 [66-68].

Both micrite and fracture-vug-fill calcite present much higher ${ }^{87} \mathrm{Sr} /{ }^{86} \mathrm{Sr}$ ratio values than Late Ordovician seawater, indicating largely introduced radiogenic Sr (Figure 9(a)). The higher ${ }^{87} \mathrm{Sr} /{ }^{86} \mathrm{Sr}$ ratios of some micrite samples may be the result of recrystallization, which was commonly observed under the microscope (Figures 5(c) and 5(d)); it could also reflect the introduction of radiogenic strontium from terrigenous clastic internal to the Lianglitag Formation [23]. For radiogenic $\mathrm{Sr}$ in calcite cement, the stratigraphic hiatuses identified in Figure 2 and burial history diagrams shown in Figure 3 suggest that there are several uplift and erosion events which could have involved the weathering of radiogenic source terrains. Radiogenic strontium could also be derived from the Precambrian basement or Lower Cambrian clastic section via circulating fluids within conductive faults and fractures that penetrate the basement in the Tazhong area [69]. ${ }^{87} \mathrm{Sr} /{ }^{86} \mathrm{Sr}$ ratio shows increasing trends from lower to upper part of the formation. Therefore, the ${ }^{87} \mathrm{Sr}$-rich fluid is probably from meteoric water leaching of clastic material in the Tahe area during the periods of tectonic uplift, and 
this is supported by a recent study from formation water geochemistry in the Tabei area [70].

Previous studies have indicated that the Lianglitag Formation carbonates are likely affected by both Early Paleozoic Caledonian and Late Paleozoic Hercynian karstification [5053]. However, because of the relatively similar characteristics in the minerals and cathodoluminescence, it is difficult to distinguish these phases. According to the stratigraphic distribution characteristics (Figure 2), one of the distinguished features of the Late Paleozoic is that the clastics are more obvious. Hence, strontium isotope may be useful in distinction between the two karsts. The strontium isotopic composition could be broadly divided into two groups (Figure 9(b)): the first group represent the Early Paleozoic karst, characterized by ${ }^{87} \mathrm{Sr} /{ }^{86} \mathrm{Sr}$ ratios that range from 0.70712 to 0.7085 , which is close to the strontium isotopic composition of the Late Ordovician seawater; the second group shows ${ }^{87} \mathrm{Sr} /{ }^{86} \mathrm{Sr}$ ratios ranging from 0.7085 to 0.71188 , significantly higher than the Late Ordovician marine strontium isotopic composition. This group represents Late Paleozoic karst, which indicates that strontium may be added by continental weathering through the river. In addition, the strontium isotopic composition of the northern part of the Tahe Oilfield (the north of the Sangtamu Fm. pinch-out boundary) is much higher, which is mainly due to the Late Paleozoic karst, whereas the strontium isotopic composition of the middle and southern parts of the Tahe Oilfield (the south of the Sangtamu Fm. pinch-out boundary) are broad and are both influenced by the Early Paleozoic and the Late Paleozoic karst, such as well S108 and well T901, which are superimposed on the two karst interactions.

\subsection{Diagenetic Fluid Evolution and Its Influence on Reservoir} Properties. Based on petrographic, isotopic, and fluid inclusion data, the diagenetic sequence is identified and divided into three main episodes. The eogenetic, mesogenetic, and telogenetic stages were used in this study [71].

During the deposition of the Lianglitag Formation, the Tahe region was characterized by a ramp and/or weakly rimmed platform, with a low-gradient slope and small-scale reefs and shoals [23]. Marine calcite cement (C1) is commonly observed (Figures 4(a) and 4(b)), especially in the southern slope facies, indicating that the Lianglitag Formation carbonates experienced strong marine cementation in the eogenetic stage. Minor fabric-selective pores occur in highenergy shoals; however, they are more commonly partly or completely filled by calcite cement (Figure 6(a)). Therefore, the carbonates exhibit intensive marine cementation and weak syndepositional freshwater dissolution during the eogenetic diagenetic stage (Figure 11(a)). Thereafter, the strata enter a shallow burial diagenetic environment where C2 calcite cement was precipitated.

The large volume of $\mathrm{C} 3$ precipitated at the wells demonstrates that the telogenetic meteoric impact is ubiquitous. In the Caledonian, the arch developed as a monocline dipping gently to the SE; as the arch was uplifted several times, three episodes of karstification, designated episodes I, II, and III, occurred during this period [52, 53]. Episode I occurred between the deposition of the Yijianfang and Qiaerbake Formations. Episode II occurred between the deposition of the Lianglitag and Sangtamu Formations. Episode III occurred between the deposition of the Ordovician Sangtamu Formation and Silurian strata. The Lianglitag Formation is mainly affected by Episode II [17]. The Lianglitag Formation carbonates were exposed to the surface and infiltrated by ground water, leading to significant dissolution of the carbonates and formation of dissolution vugs and caves with sizes from centimeters to meters (Figure 11(b)). Some vugs and caverns have been filled by minerals and/or sediments during the following mesogenetic stage (Figure 11(c)).

At the end of the Middle Devonian, because of the proximity to the South Tianshan Ocean, the northern part of the Tahe Oilfield was uplifted and subjected to subaerial erosion once again [31,36]. The Lianglitag subcrop shown in Figure 1(b) and erosional removal of the Middle Ordovician through Carboniferous section shown in Figure 2 are both the result of Hercynian uplift and erosion. Therefore, Hercynian telogenetic fluids could have laterally access to the Lianglitag Formation via the subcrop limit and result in the development of dissolution cavities (Figures 1(c) and 11(d)). Access would not necessarily require transit through the overlying Sangtamu section. Additionally, fractures are important diagenetic fluid channels for karstification. There are four periods of fault structures recognizable in the Tahe seismic profiles at present [14], which from the bottom up are as follows: (1) thrust faults developed in Cambro-Ordovician strata that formed during the Middle-Late Ordovician; (2) a strike-slip fault that developed under the $\mathrm{T}_{6}{ }^{0}$ reflecting layer (i.e., Carboniferous base boundary) and formed in the Middle-Late Devonian; (3) normal faults cutting Permian and older strata associated with early to middle Permian magmatism; and (4) thrust faults that developed in preJurassic strata and formed during the latest Permian to earliest Triassic. The Late Ordovician strata in the Tahe region are mainly affected by mid to late Devonian strikeslip faulting. Other periods of faulting are of subsidiary importance. Therefore, strike-slip faults in the Middle-Late Devonian developed and freshwater along fractures could affect the Lianglitag Formation strata.

Subsequently, the sediments were again influenced by marine to shallow burial, from which bright orange CL calcite (Cement 4) precipitated. Burial dissolution pores are locally visible (Figures 4(e), 4(f), 5(e), and 5(f)). Although late burial dissolution does occur, it is volumetrically minor. Previous studies have shown that burial dissolution mainly includes organic acids, $\mathrm{CO}_{2}, \mathrm{H}_{2} \mathrm{~S}$ [72], and deep hydrothermal dissolution $[12,73,74]$. According to Section 5.1.1, TSR and thermal fluid activity are not obvious in the Upper Ordovician Lianglitag Formation, which is consistent with the results of $\mathrm{Li}$ et al. [14]. Deeply recycled meteoric water may have entered the carbonate rocks during the late Permian favored by fracturing [75] and generated both dissolution and subsequent cementation $\mathrm{C} 6$ in vugs. As noted above, C6 was precipitated at temperatures from 130 to $200^{\circ} \mathrm{C}$ and showed significantly higher ${ }^{87} \mathrm{Sr} /{ }^{86} \mathrm{Sr}$ ratios and lighter $\delta^{18} \mathrm{O}$ and $\delta^{13} \mathrm{C}$ values. We have observed some C6 temperature and oxygen isotopic decreasing trend in distance, and the trend of 


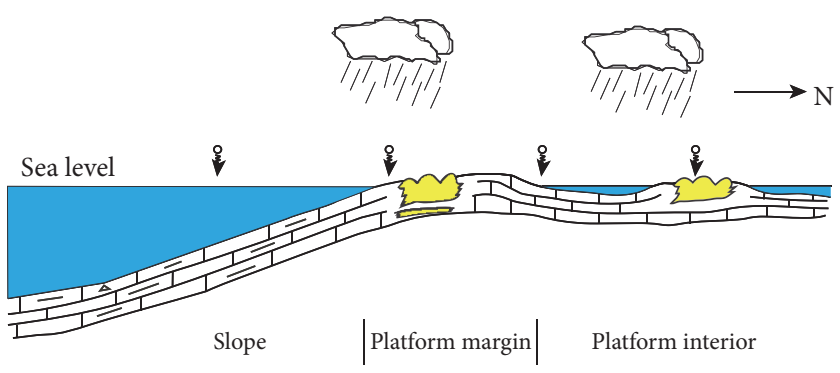

(a) Eogenetic stages

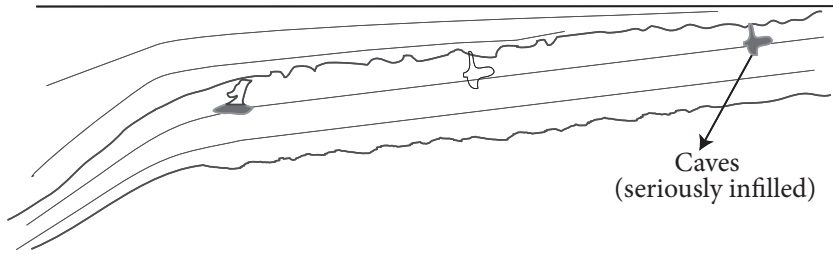

(c) Mesogenetic stages (Late Ordovician to early Devonian)

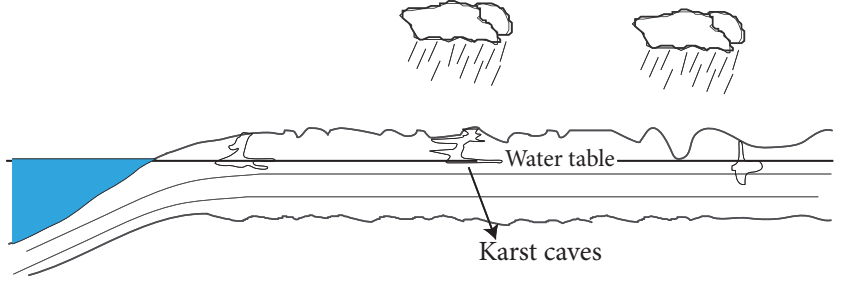

(b) Telogenetic stage-1. Caledonian diagenetic stage

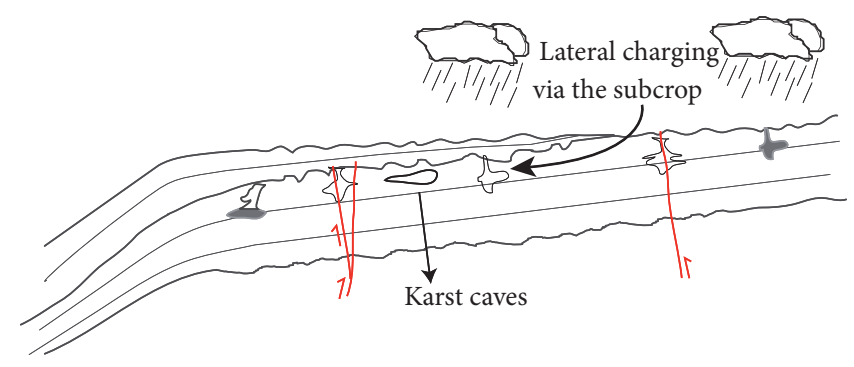

(d) Telogenetic stage-2. Hercynian diagenetic stage

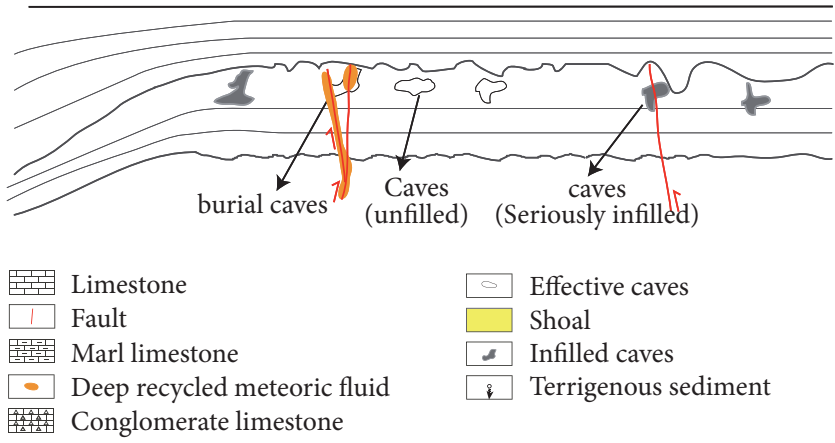

(e) Mesogenetic stages (Late Devonian to present)

FIGURE 11: Diagenetic evolution and reservoir formation models of Lianglitag Formation carbonates.

oxygen isotope values and temperatures during its pathway suggest that C6 was likely precipitated from recycling of meteoric water. Unfortunately, the data are not enough. Combined with previous works in Tarim Basin [15, 61, 62], C6 was probably closely related to deeply recycled meteoric water. The reduced water coexisted with highly mature oils with blue-white UV fluorescence emission colors. However, because most fractures in the Tahe region are partially or completely occluded by green marl, the development of deeply recycled meteoric water is very local (Figure 11(e)).

Non-fabric-selective vug and cave were produced during near-surface karst processes and later burial diagenesis forms an important class of carbonate reservoir in the Lianglitag Formation in the Tahe Oilfield. Being near surface combined with burial diagenesis produced the complex reservoirs with several scales of heterogeneity. The main controlling factor of the reservoir distribution was multistage karstification and fracturing.

\section{Conclusions}

(1) Combined with isotopic geochemical and fluid inclusion data, the corresponding diagenetic fluid was identified. The early nonluminescent $\mathrm{C} 1$ to growth zones of dark red luminescent $\mathrm{C} 2$ is a syngenetic seawater-shallow burial diagenetic environment; the subsequent nonluminescent $\mathrm{C} 3$ is related to the meteoric fluid system resulting from tectonic uplift and exposure. Then, the strata were buried again and the bright orange luminescent $\mathrm{C} 4$ zone was formed during shallow burial. The $\mathrm{C} 5$ precipitated in a middle-deep burial environment and was characterized by brown to dull luminescence. In addition, an abnormally high temperature and low salinity were found in C6 along fractures, which may be the product of deeply recycled meteoric water.

(2) The abundance of $\mathrm{Cl}$ indicates that the Lianglitag Formation carbonate suffered strong marine cementation and weak meteoric dissolution and cementation during the eogenetic diagenetic stage. The paleokarst during Caledonian II and Hercynian telogenetic karstification closely related to $\mathrm{C} 3$ constitutes the most constructive diagenesis. In addition, the carbonate was locally infected by deeply recycled meteoric water during burial. Compared with the Early Paleozoic fracture- and vug-filling calcite, the Late Paleozoic fractureand vug-filling calcite have a significantly higher ${ }^{87} \mathrm{Sr} /{ }^{86} \mathrm{Sr}$ ratio due to the presence of more terrigenous clastic material. 
(3) The reservoir system in the Tahe carbonates is dominated by non-fabric-selective pores and remanent (unfilled) karst caves. The development of the reservoir is closely related to fractures. The vugs and caves may be the result of the infiltration and dissolution of meteoric fluid along the fractures when the strata are tectonically uplifted, of high-temperature and low-salinity meteoric water circulating along the deep basin, or of the two superimposed transformations. Multistage karstification and fracturing are the main controlling factors of reservoir development, which can provide important guidance for future deep-buried oil and gas exploration, and have important economic implications.

\section{Conflicts of Interest}

The authors declare that there are no conflicts of interest regarding the publication of this paper.

\section{Acknowledgments}

This work is financially supported by the National Natural Science Foundation of China (Grant no. 41302084), Strategic Priority Research Program Grant of the Chinese Academy of Sciences (XDA14010201-02), and National Science and Technology Major Project of China (2017ZX05008-003). The authors thank Drs. Xiaoxiao Ling, Guoqiang Tang, Yu Liu, Qiuli Li, and Xianhua Li for their help during SIMS analyses in IGGCAS. Dr. Lei Jiang gave constructive advice both in English language and in logic arrangement. Many thanks are also due to Professor Chunfang Cai for constructive comments that helped to improve the manuscript.

\section{References}

[1] C. Cai, B. Mei, T. Ma, C. Chen, W. Li, and C. Liu, Approach to Fluid-Rock Interaction in the Tarim Basin, Geological Publishing House, Beijing, China, 1997.

[2] S. Morad, J. M. Ketzer, and L. R. De Ros, "Spatial and temporal distribution of diagenetic alterations in siliciclastic rocks: implications for mass transfer in sedimentary basins," Sedimentology, vol. 47, no. 1, pp. 95-120, 2000.

[3] B. Rasmussen and B. Krapez, "Evidence of hydrocarbon and metalliferous fluid migration in the Palaeoproterozoic Earaheedy Basin of Western Australia," Journal of the Geological Society, vol. 157, no. 2, pp. 355-366, 2000.

[4] J. J. Packard, I. Al-Aasm, I. Samson, Z. Berger, and J. Davies, "A Devonian hydrothermal chert reservoir: the 225 bcf parkland field, british columbia, Canada," AAPG Bulletin, vol. 85, no. 1, pp. 51-84, 2001.

[5] J. R. Boles, P. Eichhubl, G. Garven, and J. Chen, "Evolution of a hydrocarbon migration pathway along basin-bounding faults: evidence from fault cement," AAPG Bulletin, vol. 88, no. 7, pp. 947-970, 2004.

[6] S. N. Ehrenberg, G. P. Eberli, M. Keramati, and S. A. Moallemi, "Porosity-permeability relationships in interlayered limestonedolostone reservoirs," AAPG Bulletin, vol. 90, no. 1, pp. 91-114, 2006.

[7] Z. Li, D. Han, and J. Shou, "Diagenesis systems and their spatiotemporal attributes in sedimentary basins," Acta Petrologica Sinica, vol. 22, no. 8, pp. 2151-2164, 2006.
[8] S. N. Ehrenberg, P. H. Nadeau, and A. A. M. Agrawi, "A comparison of Khuff and Arab reservoir potential throughout the Middle East," AAPG Bulletin, vol. 91, no. 3, pp. 275-286, 2007.

[9] M. Moradpour, Z. Zamani, and S. A. Moallemi, "Controls on reservoir quality in the lower triassic kangan formation, Southern Persian gulf," Journal of Petroleum Geology, vol. 31, no. 4, pp. 367-385, 2008.

[10] Z. Li and J. Liu, "Key problems and research trend of diagenetic geodynamic mechanism and spatio-temporal distribution in sedimentary Basins," Acta Sedimentologica Sinica, vol. 27, pp. 837-848, 2009.

[11] Z. Li, "Research frontiers of fluid-rock interaction and oilgas formation in deep-buried basins," Bulletin of Mineralogy, Petrology and Geochemistry, vol. 35, 2016.

[12] C. Cai, K. Li, B. Li, L. Cai, and L. Jiang, "Geochemical characteristics and origins of fracture- and vug-filling of the Ordovician in Tahe Oilfield, Tarim Basin," Acta Petrologica Sinica, vol. 25, pp. 91-96, 2009.

[13] Z. Jin, D. Zhu, W. Hu, X. Zhang, J. Zhang, and Y. Song, "Mesogenetic dissolution of the middle Ordovician limestone in the Tahe oilfield of Tarim basin, NW China," Marine and Petroleum Geology, vol. 26, no. 6, pp. 753-763, 2009.

[14] Z. Li, S. Huang, J. Liu et al., "Buried diagenesis, structurally controlled thermal-fluid process and their effect on Ordovician carbonate reservoir in Tahe, Tarim Basin," Acta Sedimentologica Sinica, vol. 28, pp. 969-979, 2010.

[15] K. Li, C. Cai, H. He et al., "Origin of palaeo-waters in the Ordovician carbonates in Tahe oilfield, Tarim Basin: constraints from fluid inclusions and $\mathrm{Sr}, \mathrm{C}$ and $\mathrm{O}$ isotopes," Geofluids, vol. 11, no. 1, pp. 71-86, 2011.

[16] H. Zeng, R. Loucks, X. Janson et al., “Three-dimensional seismic geomorphology and analysis of the Ordovician paleokarst drainage system in the central Tabei Uplift, northern Tarim Basin, western China," AAPG Bulletin, vol. 95, no. 12, pp. 20612083, 2011.

[17] F. Tian, Q. Jin, X. Lu et al., "Multi-layered ordovician paleokarst reservoir detection and spatial delineation: a case study in the Tahe Oilfield, Tarim Basin, Western China," Marine and Petroleum Geology, vol. 69, pp. 53-73, 2016.

[18] C. Jia, S. Zhang, and S. Wu, Tarim Basin and the Surrounding Strata (Part II), Science Press, 2004.

[19] Z. Zhao and Z. Huang, "Ordovician conodont zones and sedimentary sequences of the Tarim Basin, Xinjiang, NW China," Journal of Stratigraphy, vol. 30, pp. 193-203, 2006.

[20] X. Cai, X. Jin, L. Zhao, Y. Yang, Z. Zhu, and M. Hu, "Classification and correlation of Lianglitag Formation of Upper Ordovician in Tarim Basin," Xinjiang Petroleum Geology, pp. 447-449, 2012.

[21] M.-C. Hou, L. Wan, H. Fu, L.-M. Zhou, L.-X. Qi, and R.$\mathrm{L}$. Yu, "Study on the sedimentary environment of the Upper Ordovician Lianglitage Formation in the south of Tarim River, China," Journal of Chengdu University of Technology, vol. 33, pp. 509-516, 2006.

[22] J. Liu, Z. Li, Y. Han, S. Peng, D. Han, and C. Xu, "Characteristics of sedimentary geochemistry and evolution of platform of the Lianglitag formation carbonate, Upper Ordovician in Tahe Oilfield," Chinese Journal of Geology, vol. 45, no. 1, pp. 278-291, 2010.

[23] J. Liu, Z. Li, J. Huang, and L. Yang, "Distinct sedimentary environments and their influences on carbonate reservoir evolution 
of the Lianglitag Formation in the Tarim Basin, Northwest China," Science China Earth Sciences, vol. 55, no. 10, pp. 16411655, 2012.

[24] Y. Lu, C. Liu, C. Du, H. Jiang, and F. Liang, "Reservoir characteristics and control factors of Lianglitag Formation of Upper Ordovician in The Tahe Oilfield," Xinjiang Geology, vol. 29, pp. 198-202, 2011.

[25] S. Buschaert, S. Fourcade, M. Cathelineau et al., "Widespread cementation induced by inflow of continental water in the eastern part of the Paris basin: $\mathrm{O}$ and $\mathrm{C}$ isotopic study of carbonate cements," Applied Geochemistry, vol. 19, no. 8, pp. 1201-1215, 2004.

[26] B. Vincent, L. Emmanuel, P. Houel, and J.-P. Loreau, "Geodynamic control on carbonate diagenesis: petrographic and isotopic investigation of the Upper Jurassic formations of the Paris Basin (France)," Sedimentary Geology, vol. 197, no. 3-4, pp. 267-289, 2007.

[27] J. Bourdet, J. Pironon, G. Levresse, and J. Tritlla, "Petroleum accumulation and leakage in a deeply buried carbonate reservoir, Níspero field (Mexico)," Marine and Petroleum Geology, vol. 27, no. 1, pp. 126-142, 2010.

[28] P. A. Cox, R. A. Wood, J. A. D. Dickson, H. B. Al Rougha, H. Shebl, and P. W. M. Corbett, "Dynamics of cementation in response to oil charge: evidence from a Cretaceous carbonate field, U.A.E," Sedimentary Geology, vol. 228, no. 3-4, pp. 246254, 2010.

[29] J. Sample, "Stable isotope constraints on vein formation and fluid evolution along a recent thrust fault in the Cascadia accretionary wedge," Earth and Planetary Science Letters, vol. 293, no. 3-4, pp. 300-312, 2010.

[30] R. I. Gabitov, A. C. Gagnon, Y. Guan, J. M. Eiler, and J. F. Adkins, "Accurate $\mathrm{Mg} / \mathrm{Ca}, \mathrm{Sr} / \mathrm{Ca}$, and $\mathrm{Ba} / \mathrm{Ca}$ ratio measurements in carbonates by SIMS and NanoSIMS and an assessment of heterogeneity in common calcium carbonate standards," Chemical Geology, vol. 356, pp. 94-108, 2013.

[31] C. Lin, H. Yang, J. Liu, Z. Rui, Z. Cai, and Y. Zhu, "Distribution and erosion of the Paleozoic tectonic unconformities in the Tarim Basin, Northwest China: significance for the evolution of paleo-uplifts and tectonic geography during deformation," Journal of Asian Earth Sciences, vol. 46, pp. 1-19, 2012.

[32] C. Jia, Tectonic Characteristic and Petroleum in Tarim Basin, China, Performance Industry Press, Beijing, China, 1997.

[33] Q. Wang and Z. Li, Basin-Mountain System and Oil and Gas in Kuche-Tianshan, Science Press, 2007.

[34] M. Jiang, J. Zhu, D. Chen, R. Zhang, and G. Qiao, "Carbon and strontium isotope variations and responses to sea-level fluctuations in the Ordovician of the Tarim Basin," Science in China Series D: Earth Sciences, vol. 44, no. 9, pp. 816-823, 2001.

[35] X. Lou, "The seismic reflection boundary $\mathrm{T}^{2}$ and the Upper Ordovician carbonate karst reservoirs on the Tazhong uplift, Xinjiang," Sedimentary Geology and Tethyan Geology, vol. 25, pp. 24-32, 2005.

[36] J. Charvet, L. Shu, S. Laurent-Charvet et al., "Palaeozoic tectonic evolution of the Tianshan belt, NW China," Science China Earth Sciences, vol. 54, no. 2, pp. 166-184, 2011.

[37] N. Qiu, S. Hu, and L. He, Theory and Application of Thermal System in Sedimentary Basin, Petroleum Industry Press, 2004.

[38] C. S. Lin, H. J. Yang, J. Y. Liu et al., "Paleostructural geomorphology of the Paleozoic central uplift belt and its constraint on the development of depositional facies in the Tarim Basin," Science in China Series D: Earth Sciences, vol. 52, no. 6, pp. 823-834, 2009.
[39] N.-S. Qiu, R. Peter, Q.-H. Mei, G. Jiang, S. Nicolesco, and C. Tao, "Application of the (U-Th)/He thermochronometry to the tectono-thermal evolution of sedimentary basin - a case history of well KQ1 in the Tarim basin," Chinese Journal of Geophysics, vol. 52, no. 7, pp. 1825-1835, 2009.

[40] R. J. Bodnar, "Revised equation and table for determining the freezing point depression of $\mathrm{H}_{2} \mathrm{O}-\mathrm{NaCl}$ solutions," Geochimica et Cosmochimica Acta, vol. 57, no. 3, pp. 683-684, 1993.

[41] R. H. Goldstein and T. J. Reynolds, Fluid inclusion, microthermometry, 1994.

[42] C. H. Moore, Carbonate Diagenesis And Porosity, Elsevier, Amsterdam, Netherlands, 1989.

[43] G. A. Shields, G. A. F. Carden, J. Veizer, T. Meidla, J.-Y. Rong, and R.-Y. Li, "Sr, C, and O isotope geochemistry of Ordovician brachiopods: a major isotopic event around the Middle-Late Ordovician transition," Geochimica et Cosmochimica Acta, vol. 67, no. 11, pp. 2005-2025, 2003.

[44] D. Fang and Z. Shen, "Phanerozoic apparent polar-wander paths of Tarim and plate motion," Journal of Zhejiang University (Science Edition, vol. 28, pp. 100-106, 2001.

[45] L. Li, N. Qiu, Z. Jin, and Z. He, "Geothermal history of Tarim Basin,” Oil \& Gas Gelology, vol. 26, pp. 613-617, 2005.

[46] J. R. O’Neil, R. N. Clayton, and T. K. Mayeda, "Oxygen isotope fractionation in divalent metal carbonates," The Journal of Chemical Physics, vol. 51, no. 12, pp. 5547-5558, 1969.

[47] B. W. Robinson and A. Gunatilaka, "Stable isotope studies and the hydrological regime of sabkhas in southern Kuwait, Arabian Gulf," Sedimentary Geology, vol. 73, no. 1-2, pp. 141-159, 1991.

[48] J. Veizer, P. Bruckschen, F. Pawellek et al., "Oxygen isotope evolution of Phanerozoic seawater," Palaeogeography, Palaeoclimatology, Palaeoecology, vol. 132, no. 1-4, pp. 159-172, 1997.

[49] A. Immenhauser, J. A. M. Kenter, G. Ganssen, J. R. Bahamonde, A. Van Vliet, and M. H. Saher, "Origin and significance of isotopes shifts in Pennslyvanian carbonates (Asturias, NW Spain)," Journal of Sedimentary Research, vol. 72, no. 1, pp. 8294, 2002.

[50] X. Yan, Z. Han, and Y. Li, "Reservoir characteristics and formation mechanism of the Ordovician carbonate pools in the Tahe Oilfield," Geological Review, vol. 48, pp. 619-626, 2002.

[51] R. Yu, "Characteristics and significance of the Caledonian karst in the Tahe Oilfield, the Tarim basin," Petroleum Geology \& Experiment, vol. 27, pp. 468-472, 2005.

[52] R. Yu and H. Fu, "Influence of tectonic movement on Ordovician carbonates of Tahe Oilfield," Nature Gas Exploration and Development, vol. 29, pp. 1-5, 2006.

[53] T. Zhang and X. Cai, "Caledonian paleo-karstification and its characteristics in Tahe area, Tarim basin," Acta Geologica Sinica, vol. 81, no. 8, pp. 1125-1134, 2007.

[54] L. A. Melim, H. Westphal, P. K. Swart, G. P. Eberli, and A. Munnecke, "Questioning carbonate diagenetic paradigms: evidence from the Neogene of the Bahamas," Marine Geology, vol. 185, no. 1-2, pp. 27-53, 2002.

[55] R. H. Worden, P. C. Smalley, and N. H. Oxtoby, "The effects of thermochemical sulfate reduction upon formation water salinity and oxygen isotopes in carbonate gas reservoirs," Geochimica et Cosmochimica Acta, vol. 60, no. 20, pp. 3925-3931, 1996.

[56] R. H. Worden, P. C. Smalley, and N. H. Oxtoby, "Gas souring by thermochemical sulfate reduction at $140^{\circ} \mathrm{C}$," AAPG Bulletin, vol. 79, no. 6, pp. 854-863, 1995.

[57] C. Cai, W. Hu, and R. H. Worden, "Thermochemical sulphate reduction in Cambro-Ordovician carbonates in Central Tarim," Marine and Petroleum Geology, vol. 18, no. 6, pp. 729-741, 2001. 
[58] H. G. Machel, "Bacterial and thermochemical sulfate reduction in diagenetic settings-old and new insights," Sedimentary Geology, vol. 140, no. 1-2, pp. 143-175, 2001.

[59] C. Cai, Q. Xiao, C. Fang, T. Wang, W. He, and H. Li, “The effect of thermochemical sulfate reduction on formation and isomerization of thiadiamondoids and diamondoids in the Lower Paleozoic petroleum pools of the Tarim Basin, NW China," Organic Geochemistry, vol. 101, pp. 49-62, 2016.

[60] H. Qing and E. Mountjoy, "Large-scale fluid flow in the Middle Devonian Presqu'ile barrier, western Canada sedimentary basin," Geology, vol. 20, no. 10, article 903, 1992.

[61] L. Jiang, W. Pan, C. Cai et al., "Fluid mixing induced by hydrothermal activity in the ordovician carbonates in Tarim Basin, China," Geofluids, vol. 15, no. 3, pp. 483-498, 2015.

[62] L. Jiang, C. Cai, R. H. Worden et al., "Multiphase dolomitization of deeply buried Cambrian petroleum reservoirs, Tarim Basin, north-west China," Sedimentology, vol. 63, no. 7, pp. 2130-2157, 2016.

[63] J. D. Hudson, "Stable isotopes and limestone lithification," Journal of the Geological Society, vol. 133, no. 6, pp. 637-660, 1977.

[64] R. E. Denison, R. B. Koepnick, W. H. Burke, and E. A. Hetherington, "Construction of the Cambrian and Ordovician seawater ${ }^{87} \mathrm{Sr} /{ }^{86} \mathrm{Sr}$ curve," Chemical Geology, vol. 152, no. 3-4, pp. 325-340, 1998.

[65] J. M. McArthur, R. J. Howarth, and T. R. Bailey, "Strontium isotope stratigraphy: LOWESS version 3: best fit to the marine Sr-isotope curve for 0-509 Ma and accompanying look-up table for deriving numerical age," Journal of Geology, vol. 109, no. 2, pp. 155-170, 2001.

[66] G. Faure, Principles of Isotope Geology, 2nd edition, 1986.

[67] J. D. Marshall, "Climatic and oceanographic isotopic signals from the carbonate rock record and their preservation," Geological Magazine, vol. 129, no. 2, pp. 143-160, 1992.

[68] J. L. Banner, "Application of the trace element and isotope geochemistry of strontium to studies of carbonate diagenesis," Sedimentology, vol. 42, no. 5, pp. 805-824, 1995.

[69] C. Cai, K. Li, H. Li, and B. Zhang, "Evidence for cross formational hot brine flow from integrated ${ }^{87} \mathrm{Sr} /{ }^{86} \mathrm{Sr}$, REE and fluid inclusions of the Ordovician veins in Central Tarim, China," Applied Geochemistry, vol. 23, no. 8, pp. 2226-2235, 2008.

[70] J. Chen, D. Liu, P. Peng, C. Yu, B. Zhang, and Z. Xiao, "The sources and formation processes of brines from the Lunnan Ordovician paleokarst reservoir, Tarim Basin, northwest China," Geofluids, vol. 13, no. 3, pp. 381-394, 2013.

[71] P. W. Choquette and L. C. Pray, "Geologic nomenclature and classification of porosity in sedimentary carbonates," $A A P G$ Bulletin, vol. 54, no. 2, pp. 207-250, 1970.

[72] S. J. Mazzullo and P. M. Harris, "Mesogenetic dissolution: its role in porosity development in carbonate reservoirs," $A A P G$ Bulletin, vol. 76, no. 5, pp. 607-620, 1992.

[73] G. R. Davies and L. B. Smith Jr., "Structurally controlled hydrothermal dolomite reservoir facies: an overview," $A A P G$ Bulletin, vol. 90, no. 11, pp. 1641-1690, 2006.

[74] Z. Jin, D. Zhu, W. Hu, X. Zhang, Y. Wang, and X. Yan, "Geological and geochemical signature of hydrothermal activity and their influence on carbonated reservoir bedside in the Tarim Basin," Acta Geologica Sinica, vol. 80, pp. 245-253, 2006.

[75] J.-W. Li, Z. Li, N.-S. Qiu, Y.-H. Zuo, J.-B. Yu, and J.-Q. Liu, "Carboniferous-Permian abnormal thermal evolution of the Tarim basin and its implication for deep structure and magmatic activity," Chinese Journal of Geophysics, vol. 59, no. 9, pp. 3318-3329, 2016. 

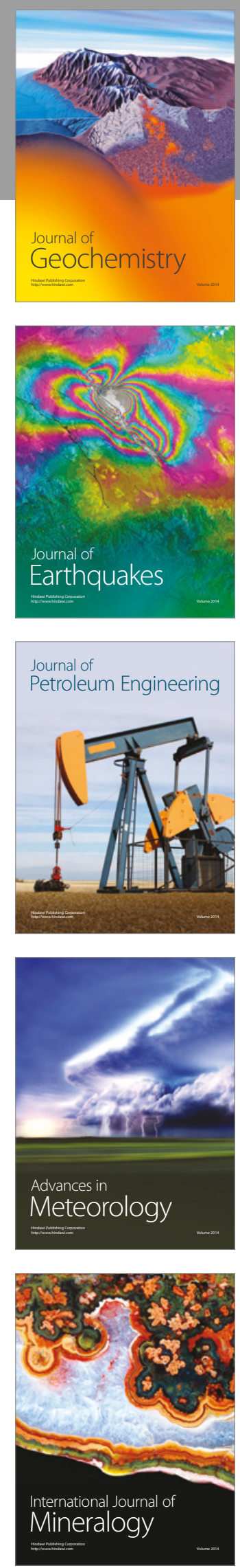
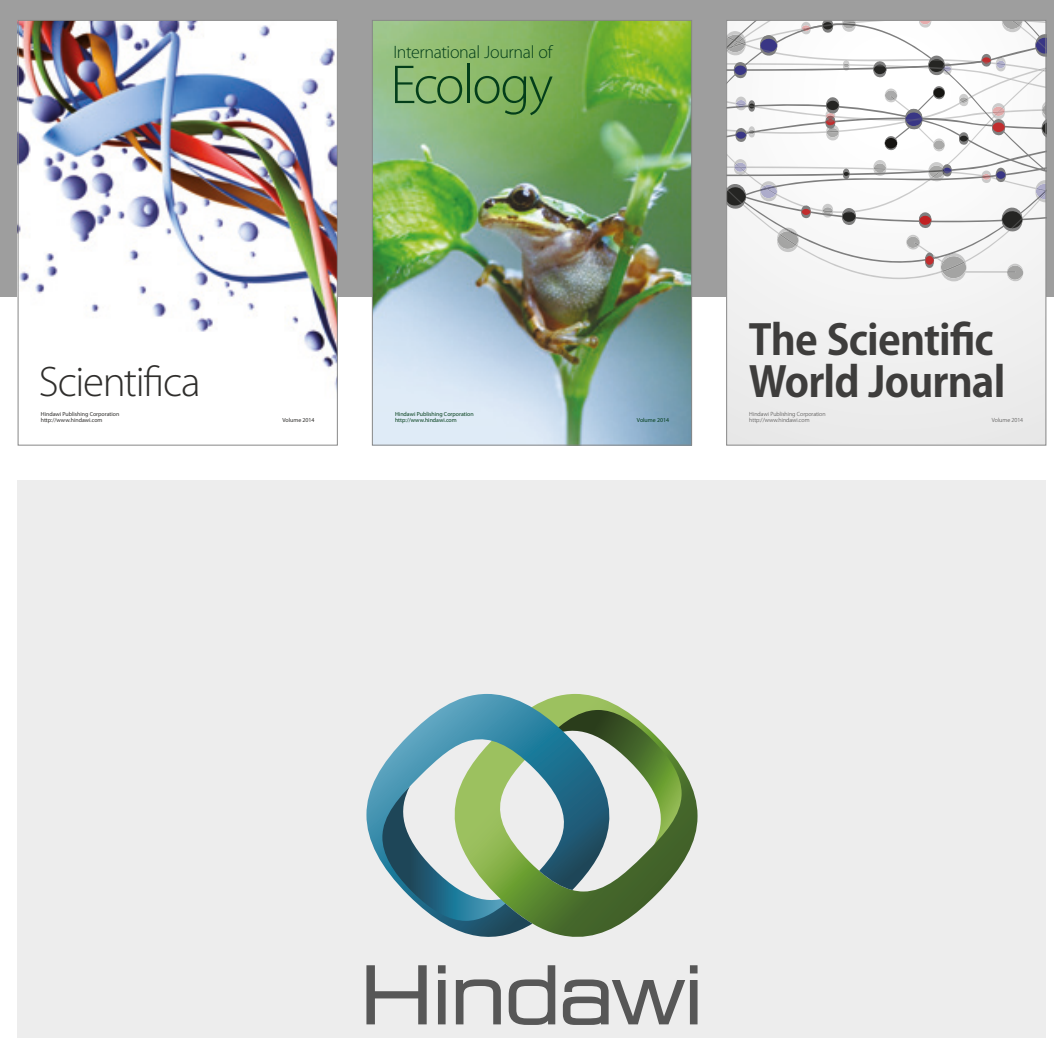

Submit your manuscripts at

https://www.hindawi.com
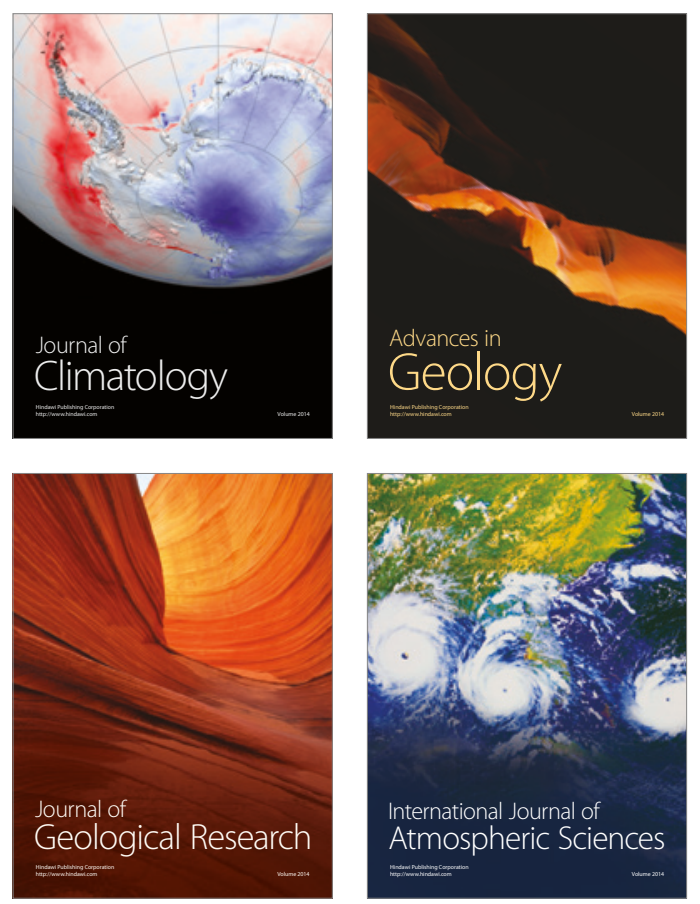

The Scientific

World Journal
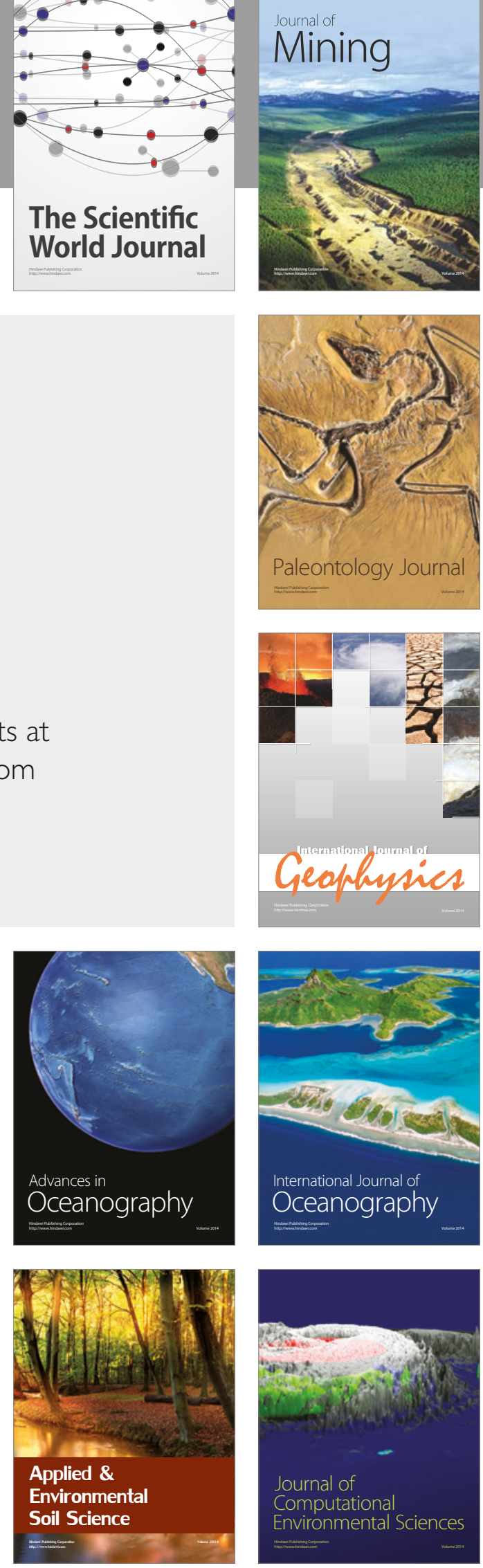